\title{
Correlation between Pregnancy Status and Severe Corona-Virus Disease Characterized by Cytokine Storm: Systematic Review and Meta-Analysis
}

\author{
John Muthuka, ${ }^{1,2 *}$ Michael Kiptoo, ${ }^{3}$ Kelly Oluoch, ${ }^{3}$ and Everlyn Nyamai ${ }^{4}$ \\ ${ }^{1}$ Department of Community Health \& Health Promotion, Kenya Medical Training College, \\ Nairobi, Kenya \\ ${ }^{2}$ College of Health Sciences, School of Public Health, Jomo Kenyatta University of Agriculture \\ \& Technology, Nairobi, Kenya \\ ${ }^{2}$ The Head-Quarters, Kenya Medical Training College, Nairobi, Kenya \\ ${ }^{3}$ The Head-Quarters, Kenya Medical Training College, Nairobi, Kenya \\ ${ }^{4}$ Principal, Kenya Medical Training College, Murang'a Campus, Kenya
}

Corresponding Author* (johnmuthuka@gmail.com) 
medRxiv preprint doi: https://doi.org/10.1101/2021.06.11.21258747; this version posted June 18, 2021. The copyright holder for this preprint (which was not certified by peer review) is the author/funder, who has granted medRxiv a license to display the preprint in perpetuity.

It is made available under a CC-BY-NC-ND 4.0 International license .

\begin{abstract}
Background. Coronavirus disease 2019 (COVID-19) is caused by severe acute respiratory syndrome coronavirus 2 (SAR2-COV-2) that identified first in Wuhan, China, in December 2019, rapidly spreading to the rest of the globe, becoming a pandemic. Some studies have eluded to an association between pregnancy status and severe COVID-19 cytokine storm, some, in contrast, have demonstrated such. The aim of the current study was to find the relationship between pregnancy status and clinical COVID-19 severity characterized by cytokine storm through a systematic review and meta-analysis approach. Methods. We searched Google Scholar, PubMed, Scopus, Web of Science, and Embase databases to identify clinical studies suitable for inclusion in this meta-analysis. Studies reporting pregnancy status and comparing the COVID-19 severity cytokine storm outcome were included. The COVID-19 severity characterized by cytokine storm was described using parameters such as; Intensive Care Unit Admission, Invasive Mechanical Ventilation, Mechanical Ventilation, Hospital Admission, Pro and Inflammatory cytokine levels, consolidation on chest CT scan, pulmonary infiltration, extreme fevers as characteristic of cytokine storm, syndromic severity, higher neutrophil count indicative of cytokine storm and severe COVI-19 presentation. Results. A total of 17 articles detailing 840332 COVID-19 women were included. Our meta-analysis revealed a relationship between positive pregnancy status and severe COVID-19 cytokine storm case (random effect model, $\mathrm{OR}=2.47 ; 95 \% \mathrm{CI}: 1.63-3.73 ; \mathrm{P}<0.0001)$, with a cumulative incidence of $6432(14.1 \%)$ among the pregnant women with COVID-19 and 24352 (3.1\%) among the non-pregnant women with COVI-19. Further to this, we found that the sub-analysis between Single Centre and Multiple Centre studies demonstrated seemingly the same as heterogeneity $\left(\mathrm{I}^{2}=72\right.$ and $\left(\mathrm{I}^{2}=98\right)$, respectively. Sensitivity analysis on each sub-group revealed that pregnancy was significantly related to severe COVID-19 with cytokine storm from single Centre studies, (fixed effect model, $\mathrm{OR}=3.97 ; 95 \% \mathrm{CI}: 2.26-6.95 ; \mathrm{P}<0.00001)$ with very low heterogeneity $\left(\mathrm{I}^{2}=\right.$ $2 \% ; \mathrm{P}=0.42$ ). Conclusion. Being pregnant is clearly associated with experiencing a severe COVID-19 characterized by a cytokine storm. The SARS-COV-2 epidemic should serve as an impetus for pregnant women diagnosed with COVID-19, and map out salient risk factors associated with its severity. The trial is registered with the International Prospective Register of Systematic Reviews (PROSPERO) CRD42021242011.
\end{abstract}

\title{
1. Introduction
}

Coronavirus disease 2019 (COVID-19), which is caused by severe acute respiratory syndrome coronavirus 2 (SAR2-COV-2), is an infectious disease caused by a newly discovered coronavirus and was first identified in Wuhan, China, in December 2019 (Sharma, 2020). It has subsequently spread across the world, causing a global pandemic. This highly contagious disease has thus far infected over 25 million people worldwide and killed over 1 Million patients, yielding a case fatality rate (CFR) that varies between 0.7 and 12.7\% (average: 3.4\%) (Worldometer, 2020).

Most people infected with the COVID-19 virus will experience mild to moderate respiratory illness and recover without requiring special treatment. Older people and those with underlying medical 
medRxiv preprint doi: https://doi.org/10.1101/2021.06.11.21258747; this version posted June 18, 2021. The copyright holder for this preprint (which was not certified by peer review) is the author/funder, who has granted medRxiv a license to display the preprint in perpetuity. It is made available under a CC-BY-NC-ND 4.0 International license .

problems like cardiovascular disease, diabetes, chronic respiratory disease, and cancer are more likely to develop serious illnesses (Handayani et al., 2020).

COVID-19 primarily targets lung epithelial cells, causing viral pneumonia and acute respiratory distress syndrome (ARDS), especially in elderly patients. Therefore, mortality is higher in the elderly and in patients with at least one accompanying comorbid disease (Yang et al., 2020). In the last report issued by the Centers for Disease Control and Prevention Institute, the incidence of respiratory disease was $9.2 \%$ in patients diagnosed with a severe COVID-19 clinical course (Chow et al., 2020). Chronic obstructive pulmonary disease (COPD) and asthma are also common comorbidities in severe cases and are reported in $10.8 \%$ and $17.0 \%$, respectively, of hospitalized patients aged $\geq 18$ years with COVID-19 (Garg et al., 2020).

COVID-19 infection has a heterogeneous disease course; it may be asymptomatic or causes only mild symptoms in the majority of the cases (Gerasimov et al., 2020), while immunologic complications such as macrophage activation syndrome also known as secondary hem phagocytic lymphohistiocytosis, resulting in cytokine storm syndrome and acute respiratory distress syndrome, may also occur in some patients (Hu et al., 2021). The immune system is there to help us fight infection, but sometimes it wreaks more havoc than the disease itself. Most of the COVID19 patients experiencing cytokine storms are presenting with fevers and shortness of breath, then having so much difficulty breathing they eventually require ventilation. This event may be related to pregnancy status, as a severe presentation (Bhaskar et al., 2020)

Pregnant women who have COVID-19 appear more likely to develop respiratory complications requiring intensive care than women who aren't pregnant, according to the Centers for Disease Control and Prevention (Ellington et al., 2020). Pregnant women are also more likely to be placed on a ventilator. Some research suggests that pregnant women with COVID-19 are also more likely to have a premature birth and cesarean delivery, and their babies are more likely to be admitted to a neonatal unit (Barile et al., 2020).

Pregnant women are a potentially highly vulnerable population due to anatomical, physiological, and immunological changes under the COVID-19 pandemic. Issues related to pregnancy with COVID-19 attracted widespread attention from researchers. A large number of articles were published aiming to elaborate on clinical characteristics and outcomes of pregnant women infected 
medRxiv preprint doi: https://doi.org/10.1101/2021.06.11.21258747; this version posted June 18, 2021. The copyright holder for this preprint (which was not certified by peer review) is the author/funder, who has granted medRxiv a license to display the preprint in perpetuity.

It is made available under a CC-BY-NC-ND 4.0 International license .

with COVID-19, in order to provide evidence for management. The existing data suggest that the overall prognosis of pregnancy with COVID-19 is promising when compared with that of other previous coronaviruses. There is still maternal morbidity and mortality related to COVID-19 reported (Chen et al., 2020).

There are many unknowns for pregnant women during the coronavirus disease 2019 (COVID-19) pandemic. Clinical experience of pregnancies complicated with infection by other coronaviruses e.g., Severe Acute Respiratory Syndrome (SARS) and Middle Eastern Respiratory Syndrome, has led to a pregnant woman being considered potentially vulnerable to severe SARS-CoV-2 infection. Physiological changes during pregnancy have a significant impact on the immune system, respiratory system, cardiovascular function, and coagulation (Wastnedge et al., 2021).

Given diverging findings in the existing literature, we systematically reviewed English-language studies to investigate whether the pregnancy was associated with a more severe clinical course of COVID-19.

\section{Material and Methods}

All guidelines listed in the Preferred Reporting Items for Systematic Reviews and Meta-Analyses (PRISMA) statement were followed in conducting this meta-analysis (Moher et al., 2016). The current methodological systematic review and meta-analysis pooled data from observational studies including cohort, case-control, cross-sectional and similar viable case studies and was recorded in the International Prospective Register of Systematic Reviews https://www.crd.york.ac.uk/PROSPERO/\#myprospero; registration number: CRD42021242011

\subsection{Study Search Strategy}

We searched by a simple search in Google Scholar, PubMed, Scopus, Web of Science, and Embase databases to identify observational studies suitable for inclusion here with search terms; severe Covid-19 and pregnancy and moving on to other keywords, that is; pregnancy, severe cytokine storm, covid-19 (corona-virus, all in English for the period beginning from March 2020 to March 2021. The following search terms were used: "COVID-19," OR "SARS-COV-2," OR "novel coronavirus (CoV)," AND "pregnant," OR "gestation," AND “clinical features," OR “characteristic," AND “severity," OR “severe”. 
medRxiv preprint doi: https://doi.org/10.1101/2021.06.11.21258747; this version posted June 18, 2021. The copyright holder for this preprint (which was not certified by peer review) is the author/funder, who has granted medRxiv a license to display the preprint in perpetuity.

It is made available under a CC-BY-NC-ND 4.0 International license .

\subsection{Inclusion and Exclusion Criteria}

Inclusion criteria were as follows: (i) studies that examined COVID-19 women within reproductive age and diagnosed COVID-19 according to WHO criteria; (ii) observational, crosssectional, prospective, or retrospective studies; (iii) studies that compared pregnant women versus non-pregnant women with severe COVID-19 characterized by cytokine storm; (iv) studies evaluating the clinical prognosis in pregnancy and the immunological profile at any gestation stage and looking at the pro-inflammatory response, covid-19 disease and the hallmark outcome, the severe cytokine storm

Exclusion criteria were as follows: (i) unrelated, duplicated, and contain information answering our research question, (ii) non-English-language studies, (iii) case reports/series, (iv) reviews, (v) editorial letters, (vi) studies lacking a full-text (unavailable or not yet published), (vii) studies without a DOI, and (viii) studies with small sample sizes ( $<50$ patients) because of low statistical power.

\subsection{Data Extraction}

Extraction of both adjusted and non-adjusted data was be performed to give the most allowed confounding factor which would be used in the analysis by pooling them later. A researcher (JM) scanned study titles and abstracts obtained via an initial database search and included relevant ones in a secondary pool. Next, two independent researchers (MK and KO) evaluated the full text of these articles to determine whether they met study inclusion criteria. Any disputes were resolved by discussion and negotiation with a third investigator (MK). Agreed-upon studies were included in the final meta-analysis.

The following data were obtained from all studies: title, first author, publication year, location, sample size, age (median), pregnancy status (pregnant or non-pregnant), and severe COVID-19 cytokine storm presentation. Given these two groups, we were able to map out who developed the severe COVID-19 cytokine storm between them.

\subsection{Risk of Bias (Quality) Assessment}

$\mathrm{NIH}$ tool for observational and cross-sectional was used in this study 2-3 reviewers independently assessed the quality of the studies and added to the data extraction form before the inclusion into 
medRxiv preprint doi: https://doi.org/10.1101/2021.06.11.21258747; this version posted June 18, 2021. The copyright holder for this preprint (which was not certified by peer review) is the author/funder, who has granted medRxiv a license to display the preprint in perpetuity.

It is made available under a CC-BY-NC-ND 4.0 International license .

the analysis to reduce the risk of bias. To evaluate the risk of bias, reviewers rated each of the 14 items into dichotomous variables: yes, no, or not applicable. An overall score was calculated by adding all the items' scores as yes equals one, while no and NA equals zero. A score was given for every paper to classify them as poor, fair, or good conducted studies, where a score from 0 to 5 was considered poor, 6 to 9 as fair, and 10 to 14 as good. Data checking was done ideally by not the ones who performed the extraction of those articles or each reviewer was assigned a different article than the one he extracted in the previous.

\subsection{Statistical Analyses}

RevMan 5.4.1 (Review Manager 5.4.1 at http://community.cochrane.org/tools/review-productiontools/revman-5/revman-5) was used to calculate odds ratios with $95 \%$ confidence intervals, which are depicted using forest plots. Quantitative numbers were measured in terms of total numbers and percentages (\%). The odds ratio of severe COVID-19 cytokine storm among pregnant and nonpregnant women was calculated. Heterogeneity was evaluated with Cochran's Q and the Higgins test. The Higgins test uses a fixed-effect model when $<50 \%$, and a random-effects model when $>50 \%$. When heterogeneity was detected, a sensitivity adjustment was made to determine its source. This procedure was performed by leaving one study out of the analysis at a time, with a fixed-effect model used after excluding heterogeneity. Subgroup, cumulative analyses, and metaregression were used to test whether the results are consistent or not and investigate the effect of confounders on the outcome (cytokine storm) and elucidate the best predictors in pregnancy status among women with Covid-19. Publication bias was evaluated using the Cochrane Risk of Bias tool.

\section{Results}

Our initial search of international databases using the keywords described above yielded 221 articles. After excluding 70 duplicate articles, 151 articles remained. When article titles and abstracts were evaluated for appropriateness, an ultimate 29 articles met the inclusion criteria. In addition, 12 further meeting the exclusion criteria were excluded for which full texts were obtained. A total of 17 articles met all our criteria. The relevant PRISMA study flow chart is shown in Figure 1. A quality analysis of the pooled articles included in this meta-analysis was done by 
medRxiv preprint doi: https://doi.org/10.1101/2021.06.11.21258747; this version posted June 18, 2021. The copyright holder for this preprint (which was not certified by peer review) is the author/funder, who has granted medRxiv a license to display the preprint in perpetuity.

It is made available under a CC-BY-NC-ND 4.0 International license .

applying NOS. As a result, overall quality was found to be moderate (NOS score min: 5, max: 8).

Results of a quality analysis of the pooled articles are available in Table 1.

\section{Figure 1}

\section{PRISMA flow diagram of study selection procedures}

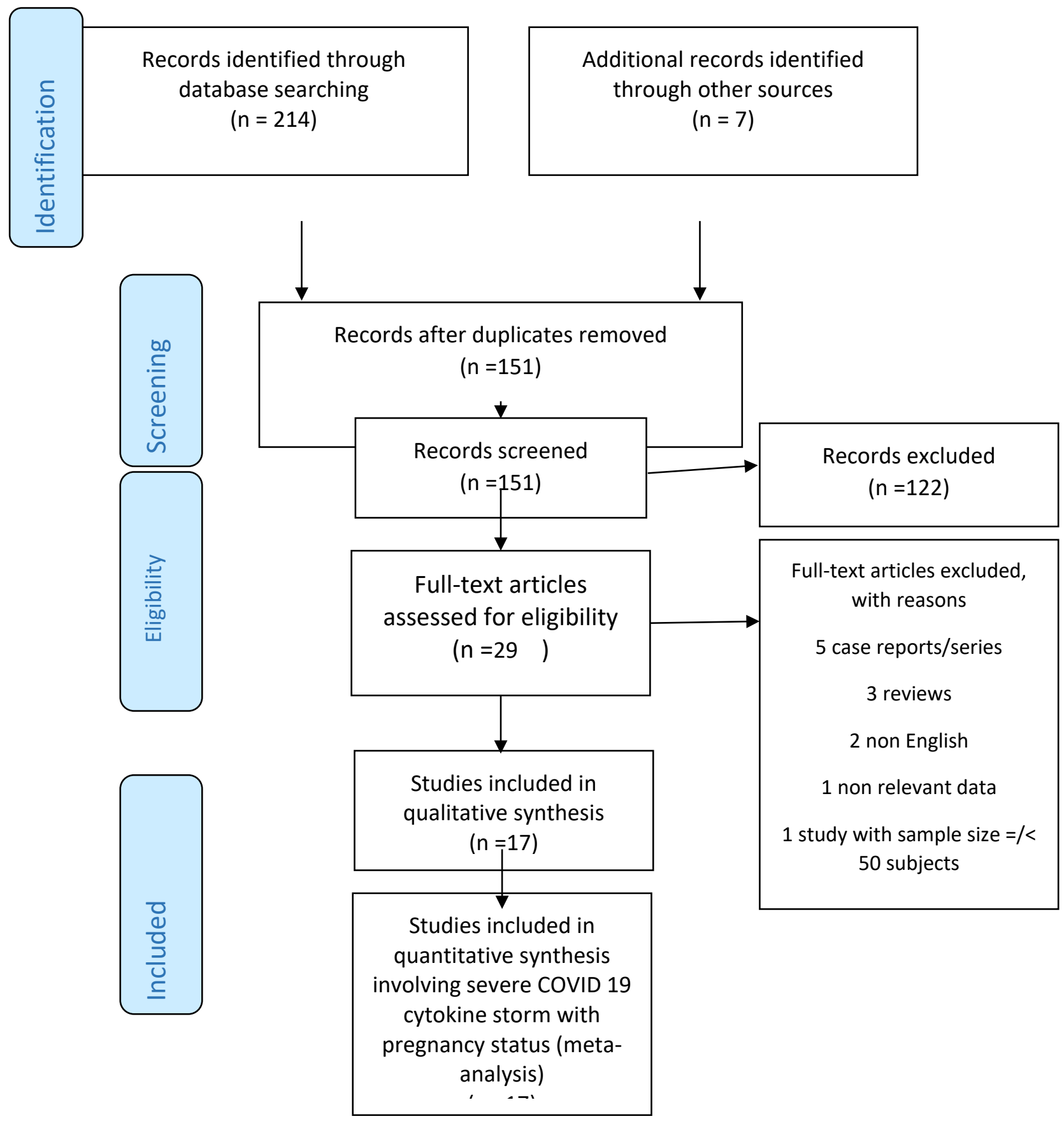


medRxiv preprint doi: https://doi.org/10.1101/2021.06.11.21258747; this version posted June 18, 2021. The copyright holder for this preprint (which was not certified by peer review) is the author/funder, who has granted medRxiv a license to display the preprint in perpetuity. It is made available under a CC-BY-NC-ND 4.0 International license .

\subsection{Features of the Included Studies}

In this meta-analysis pool, 840417 women diagnosed with COVID-19 from 17 studies [4, 10-24] were included. This inclusion utilized the predefined given CDC reporting guidelines on COVID19 diagnosis (Chow et al., 2020), 85 patients whose specific parameters of consideration on the severity of COVID-19 defined with cytokine storm statuses were reported as "unknown" or not tabulated were excluded from the final analysis, yielding a final 840332 patients. Of these, 45571 (5.4\%) were pregnant women diagnosed with COVID-19, while 794761 (94.6\%) were nonpregnant women diagnosed with COVID-19. Among the pregnant COVID-19 diagnosed women, the total events of the severity of COVID-19 with cytokine storm were 6432 (14.1\%) and among the non-pregnant COVID-19 diagnosed women were 24352 (3.1\%). The total events of COVID19 severity occurring with cytokine storm and ascertained by a specific parameter were 30784 (3.7\%) with the cumulative incidence from all studies ranging from 0.4 to $90.7 \%$ (average: $36.26 \%$ ). Parameter of comparison on COVID 19 severity with cytokine storm was implicated by ICU admission in three studies, by ICU plus mechanical ventilation in two studies, three by higher levels of inflammatory response markers, one by consolidation on chest CT scan, one by pulmonary infiltration, one by extreme fevers as characteristic of cytokine storm, one by syndromic severity, one by hospital admission, two by severe COVI-19 presentation, one by invasive mechanical ventilation and one by higher neutrophil count indicative of cytokine storm. The included studies were; fifteen retrospective (six multicenter and 9 single-center) and two prospective (both multicenter). A summary of the studies included in this meta-analysis is available in Table 1.

The main outcome of this meta-analysis was the possible association of pregnancy and severe COVID-19 characterized by cytokine storm which was indicated by a specific prognosis and event such as, ICU admission or such as shown in Table 1. We assessed the quality of the included observational studies based on a modified version of the Newcastle-Ottawa Scale (NOS) which consists of 8 items with 3 subscales, and the total maximum score of these 3 subsets is 9 . We considered a study that scored $\geq 7$ a high-quality study since a standard criterion for what constitutes a high-quality study has not yet been universally established. The 17 studies assessed by us generated a mean value of 6.47 and as result, the overall quality was found to be moderate (NOS score min: 5, max: 8).as indicated in Table 2. 
medRxiv preprint doi: https://doi.org/10.1101/2021.06.11.21258747; this version posted June 18, 2021. The copyright holder for this preprint (which was not certified by peer review) is the author/funder, who has granted medRxiv a license to display the preprint in perpetuity.

Table 1: Features of the studies included in the meta-analysis

\begin{tabular}{|c|c|c|c|c|c|c|}
\hline First author & $\begin{array}{l}\text { Location of } \\
\text { patients }\end{array}$ & $\begin{array}{l}\text { Study } \\
\text { design }\end{array}$ & $\begin{array}{l}\text { Parameter of comparison on COVID } 19 \text { severity } \\
\text { with cytokine storm }\end{array}$ & $\begin{array}{c}\text { Events in } \\
\text { Pregnant/ total in } \\
\text { Cohort }\end{array}$ & $\begin{array}{l}\text { Events in Non- } \\
\text { Pregnant/total in } \\
\text { cohort }\end{array}$ & $\begin{array}{l}\text { Cumulative incidence of } \\
\text { severe COVID-19 defined by } \\
\text { cytokine storm }\end{array}$ \\
\hline Badr et al, 2020 & $\begin{array}{l}\text { France and } \\
\text { Belgium }\end{array}$ & $\mathrm{CC}, \mathrm{MC}$ & ICU vs No ICU Admission & $58 / 83$ & $17 / 107$ & $75[39 \%]$ \\
\hline Blitz et al, 2020 & $\begin{array}{l}\text { New York, } \\
\text { USA }\end{array}$ & $\underset{\text { MC }}{\mathbf{R}, \mathbf{O}}$ & ICU vs No ICU Admission & $8 / 82$ & $50 / 332$ & $58[14 \%]$ \\
\hline CDC, 2020 & USA & $\begin{array}{l}\mathbf{P}, \mathbf{C}, \\
\text { MC }\end{array}$ & $\begin{array}{l}\text { ICU plus mechanical ventilation vs No ICU } \\
\text { Admission with mechanical ventilation }\end{array}$ & $2583 / 8200$ & $15840 / 316800$ & $18423[5.7 \%]$ \\
\hline Chen B et al 2020 & $\begin{array}{l}\text { Wuhan, } \\
\text { China }\end{array}$ & $\mathrm{R}, \mathrm{SC}$ & higher level of inflammation markers vs Lower & $0 / 31$ & $1 / 80$ & $1[0.9 \%]$ \\
\hline Collin et al, 2020 & Sweden & $\mathrm{R}, \mathrm{MC}$ & $\begin{array}{l}\text { invasive mechanical ventilation vs no invasive } \\
\text { mechanical ventilation }\end{array}$ & $7 / 13$ & $29 / 40$ & $36[68 \%]$ \\
\hline $\begin{array}{l}\text { ELLINGTON et al, } \\
2020\end{array}$ & USA & $\mathrm{R}, \mathrm{OMC}$ & ICU with MV vs no ICU MV & $2587 / 8207$ & $4840 / 83205$ & $7427[8 \%]$ \\
\hline Fang Liu et al, 2020 & $\begin{array}{l}\text { Wuhan, } \\
\text { China }\end{array}$ & $\begin{array}{l}\mathrm{R}, \mathrm{CC} \\
\mathrm{SC}\end{array}$ & $\begin{array}{l}\text { Consolidation on chest CT vs no consolidation on } \\
\text { chest CT }\end{array}$ & $20 / 21$ & $16 / 19$ & $36[90 \%]$ \\
\hline $\begin{array}{l}\text { MartinezPortilla et } \\
\text { al } 2020\end{array}$ & Mexico & $\mathrm{R}, \mathrm{MC}$ & ICU/Death vs non ICU/Death & $752 / 5183$ & $446 / 5183$ & $1198[12 \%]$ \\
\hline $\begin{array}{l}\text { Ming-Zhu Yin et al, } \\
2020\end{array}$ & China & $\mathbf{R}, \mathbf{C}, \mathbf{S C}$ & $\begin{array}{l}\text { Severe or critical COVID-19 characterized by } \\
\text { higher levels of inflammatory indices of cytokine } \\
\text { storm vs Moderate COVI-19 }\end{array}$ & $19 / 31$ & $11 / 35$ & $30[46 \%]$ \\
\hline $\begin{array}{l}\text { Mohr-Sasson et al, } \\
2020\end{array}$ & $\begin{array}{l}\text { Fuyang, } \\
\text { China }\end{array}$ & $\mathrm{R}, \mathrm{C}, \mathrm{SC}$ & High vs low fevers & $3 / 11$ & $15 / 25$ & $18[50 \%]$ \\
\hline Molteni E, etal 2020 & $\begin{array}{l}\text { UK, } \\
\text { SWEDEN } \\
\text { \&USA }\end{array}$ & $\begin{array}{l}\mathbf{P}, \mathbf{O}, \\
\text { MC }\end{array}$ & syndromic severity vs non syndromic severity & $87 / 140$ & $1508 / 2515$ & $1595[60 \%]$ \\
\hline Oakes et al, 2020 & $\begin{array}{l}\text { Wuhan, } \\
\text { China }\end{array}$ & $\mathrm{R}, \mathrm{C}, \mathrm{SC}$ & Hospital admission vs non-admission & $7 / 22$ & $17 / 240$ & $24[9 \%]$ \\
\hline $\begin{array}{l}\text { Qiancheng et al, } \\
2021\end{array}$ & $\begin{array}{l}\text { Wuhan, } \\
\text { China }\end{array}$ & $\mathrm{R}, \mathrm{SC}$ & Non severe vs. severe & $2 / 28$ & $1 / 54$ & $3[9.8 \%]$ \\
\hline Wang $Z$ et al 2020 & $\begin{array}{l}\text { Wuhan, } \\
\text { China }\end{array}$ & $\mathrm{R}, \mathrm{SC}$ & Covid-19 Manifestations on chest $\mathrm{CT} /$ non & $22 / 30$ & $42 / 42$ & $64[89 \%]$ \\
\hline Wei L et al 2020 & $\begin{array}{l}\text { Wuhan, } \\
\text { China }\end{array}$ & $\mathrm{R}, \mathrm{SC}$ & $\begin{array}{l}\text { Higher vs lower neutrophil count as indicative of } \\
\text { cytokine storm }\end{array}$ & $15 / 17$ & $24 / 26$ & $39[91 \%]$ \\
\hline Xu S et al 2020 & $\begin{array}{l}\text { Wuhan, } \\
\text { China }\end{array}$ & $\mathbf{R},, \mathrm{SC}$ & Pulmonary infiltration vs no pulmonary infiltration & $17 / 34$ & $3 / 30$ & $20[31 \%]$ \\
\hline $\begin{array}{l}\text { Zambrano etal, } \\
2020\end{array}$ & USA & $\mathrm{R}, \mathrm{MC}$ & $\begin{array}{l}\text { Severe COVID-19-associated illness vs Mild to } \\
\text { moderate }\end{array}$ & $245 / 23434$ & $1492 / 386,028$ & $1737[0.4 \%]$ \\
\hline
\end{tabular}

R: retrospective; CS: cross-sectional; O: observational; ICU: intensive care unit; SC: singlecenter; MC: multicenter; CC: case-control; P: prospective; 
medRxiv preprint doi: https://doi.org/10.1101/2021.06.11.21258747; this version posted June 18, 2021. The copyright holder for this preprint (which was not certified by peer review) is the author/funder, who has granted medRxiv a license to display the preprint in perpetuity.

It is made available under a CC-BY-NC-ND 4.0 International license .

Table 2: Newcastle-Ottawa scale for quality assessment and risk of bias.

\begin{tabular}{|c|c|c|c|c|c|}
\hline Study/Year & Year & $\begin{array}{l}\text { Case selection (max. } \\
4)\end{array}$ & $\begin{array}{l}\text { Comparability (max. } \\
2 \text { ) }\end{array}$ & $\begin{array}{l}\text { Exposure/outcome (max. } \\
3 \text { ) }\end{array}$ & $\begin{array}{l}\text { Total } \\
\text { score }\end{array}$ \\
\hline (Badr et al., 2020) & 2020 & $* * *$ & $* *$ & $* *$ & 7 \\
\hline (Blitz et al., 2020) & 2020 & $* * *$ & $* *$ & $*$ & 6 \\
\hline $\begin{array}{l}\text { (Centers for } \\
\text { Disease Control } \\
\text { and Prevention, } \\
2020 \text { ) }\end{array}$ & 2020 & $* * * *$ & $* *$ & $* *$ & 8 \\
\hline (Cheng et al., 2020) & 2020 & $* * *$ & $*$ & $* *$ & 6 \\
\hline (Collin et al., 2020) & 2020 & $* * * *$ & $*$ & $* *$ & 7 \\
\hline $\begin{array}{l}\text { (Ellington et al., } \\
2020)\end{array}$ & 2020 & $* * *$ & $* *$ & $* * *$ & 7 \\
\hline (Liu et al., 2020) & 2020 & $* * *$ & $*$ & $* *$ & 6 \\
\hline $\begin{array}{l}\text { (Martinez-Portilla } \\
\text { et al., 2021) }\end{array}$ & 2020 & $* * *$ & * & $* *$ & 6 \\
\hline (Yin et al., 2020) & 2020 & $* * *$ & $* *$ & $* *$ & 7 \\
\hline $\begin{array}{l}\text { (Mohr-Sasson et } \\
\text { al., 2020) }\end{array}$ & 2020 & $* * *$ & $*$ & $*$ & 5 \\
\hline $\begin{array}{l}\text { (Molteni et al., } \\
\text { 2020) }\end{array}$ & 2020 & $* * *$ & $*$ & $* *$ & 6 \\
\hline (Oakes et al., 2021) & 2020 & $* * *$ & $* *$ & $* *$ & 7 \\
\hline $\begin{array}{l}\text { (Qiancheng et al., } \\
\text { 2020) }\end{array}$ & 2021 & $* * *$ & * & $* *$ & 6 \\
\hline (Wang et al., 2020) & 2020 & $* *$ & $* *$ & $* *$ & 6 \\
\hline (Wei et al., 2020) & 2020 & $* * *$ & $*$ & $* * *$ & 7 \\
\hline (Xu et al., 2020) & 2020 & $* * *$ & $* *$ & $* *$ & 6 \\
\hline $\begin{array}{l}\text { (Zambrano et al, } \\
\text { 2020) }\end{array}$ & 2020 & $* * *$ & * & $* * *$ & 7 \\
\hline
\end{tabular}

\subsection{Pregnancy status and COVID-19 Severity characterized by Cytokine Storm}

The cumulative incidence of severe COVID-19 characterized by Cytokine Storm as ascertained by a specific indicator among pregnant women was 6432/45571(14.1\%), while among nonpregnant women, it was 24352/794761 (3.1\%). A meta-analysis revealed a significant association between pregnancy status and severe COVID-19 with cytokine storm (random effect model, $\mathrm{OR}=2.47$; 95\% CI: 1.63-3.73; $\mathrm{P}<0.0001$ ) (Table 3) (Figure 2(a)). A funnel plot was used to 
medRxiv preprint doi: https://doi.org/10.1101/2021.06.11.21258747; this version posted June 18, 2021. The copyright holder for this preprint (which was not certified by peer review) is the author/funder, who has granted medRxiv a license to display the preprint in perpetuity. It is made available under a CC-BY-NC-ND 4.0 International license .

evaluate publication bias and revealed considerable heterogeneity between all the pooled studies $\left(\mathrm{I}^{2}=98 \% ; \mathrm{P}<0.00001\right)$ (Figure 2(b)). A sensitivity analysis was performed to explore the impact of excluding or including the cumulative incidence of severe COVID-19 characterized by Cytokine Storm as ascertained by a specific indicator among pregnant women was 6432/45571(14.1\%), while among non-pregnant women, it was 24352/794761 (3.1\%). A metaanalysis revealed a significant association between pregnancy status and severe COVID-19 with cytokine storm (random effect model, $\mathrm{OR}=2.47$; 95\% CI: 1.63-3.73; P < 0.0001) (Table 3) (Figure 2(a)). A funnel plot was used to evaluate publication bias and revealed considerable heterogeneity between all the pooled studies $\left(I^{2}=98 \%\right.$; $\left.<0.00001\right)$ (Figure 2(b)). A sensitivity analysis was performed to explore the impact of excluding or including studies in a meta-analysis based on sample size, methodological quality, and variance. After removing eight studies (Blitz et al., 2020; Centers for Disease Control and Prevention, 2020; Collin et al., 2020; Martinez-Portilla et al., 2021; Mohr-Sasson et al., 2020; Molteni et al., 2020; Wang et al., 2020; Zambrano et al., 2020), which were major causes of heterogeneity, revealed that pregnancy was significantly related to severe COVID-19 with cytokine storm (fixed effect model, OR=7.41;95\% CI: 7.02-7.83; P< 0.00001). Furthermore, this updated analysis showed substantially low heterogeneity $\left(\mathrm{I}^{2}=29 \%\right.$; $\mathrm{P}=0.19$;), while a funnel plot revealed no publication bias (Figure 2(d)).g studies in a metaanalysis based on sample size, methodological quality, and variance. After removing eight studies (Blitz et al., 2020; Centers for Disease Control and Prevention, 2020; Collin et al., 2020; MartinezPortilla et al., 2021; Mohr-Sasson et al., 2020; Molteni et al., 2020; Wang et al., 2020; Zambrano et al., 2020), which were major causes of heterogeneity, revealed that pregnancy was significantly related to severe COVID-19 with cytokine storm (fixed effect model, OR=7.41; 95\% CI: 7.027.83; $\mathrm{P}<0.00001)$. Furthermore, this updated analysis showed substantially low heterogeneity $\left(\mathrm{I}^{2}\right.$ $=29 \% ; \mathrm{P}=0.19 ;$ ), while a funnel plot revealed no publication bias (Figure 2(d)). 
medRxiv preprint doi: https://doi.org/10.1101/2021.06.11.21258747; this version posted June 18, 2021. The copyright holder for this preprint (which was not certified by peer review) is the author/funder, who has granted medRxiv a license to display the preprint in perpetuity.

It is made available under a CC-BY-NC-ND 4.0 International license .

Table 3: Events in pregnant and non-pregnant women

\begin{tabular}{|l|l|l|l|l|l|l|}
\hline Studies & \multicolumn{3}{|l|}{ Pregnant with COVID-19 } & \multicolumn{3}{l|}{ Non-Pregnant with COVID-19 } \\
\hline Authors & Events & Total & $\%$ & Events & Total & $\%$ \\
\hline Badr et al, 2020 & 58 & 87 & 66.7 & 17 & 107 & 15.9 \\
\hline Blitz et al, 2020 & 8 & 82 & 9.75 & 50 & 332 & 15.1 \\
\hline CARL CDC, 2020 & 2583 & 8200 & 31.5 & 15840 & 316800 & 5 \\
\hline Chenf B et al 2020 & 0 & 31 & 0 & 1 & 80 & 1.25 \\
\hline Collin et al, 2020 & 7 & 13 & 53.8 & 29 & 40 & 72.5 \\
\hline Ellington et al, 2020 & 2587 & 8207 & 31.5 & 4840 & 83205 & 5.9 \\
\hline Fang Liu et al, 2020 & 20 & 21 & 95.3 & 16 & 19 & 84.2 \\
\hline Martinez et al 2020 & 752 & 5183 & 14.5 & 446 & 5183 & 8.6 \\
\hline $\begin{array}{l}\text { Ming-Zhu Yin et al, } \\
\text { 2020 }\end{array}$ & 19 & 31 & 61.3 & 11 & 35 & 31.4 \\
\hline $\begin{array}{l}\text { Mohr-Sasson et al, } \\
\text { 2020 }\end{array}$ & 3 & 11 & 27.2 & 15 & 25 & 60 \\
\hline Molteni E, etal 2020 & 87 & 140 & 62.1 & 1508 & 2515 & 59.9 \\
\hline Oakes et al, 2020 & 7 & 22 & 31.8 & 17 & 240 & 7.08 \\
\hline Qiancheng et al, 2020 & 2 & 28 & 7.14 & 1 & 54 & 1.85 \\
\hline Wang Z et al 2020 & 22 & 30 & 73.3 & 42 & 42 & 100 \\
\hline Wei L et al 2020 & 15 & 17 & 88.2 & 24 & 26 & 92.3 \\
\hline Xu S et al 2020 & 17 & 34 & 50 & 3 & 30 & 10 \\
\hline Zambrano et al, 2020 & 245 & 23434 & 1.05 & 1492 & 386028 & 0.4 \\
\hline & & & & & & \\
\hline
\end{tabular}


medRxiv preprint doi: https://doi.org/10.1101/2021.06.11.21258747; this version posted June 18, 2021. The copyright holder for this preprint (which was not certified by peer review) is the author/funder, who has granted medRxiv a license to display the preprint in perpetuity.

It is made available under a CC-BY-NC-ND 4.0 International license .

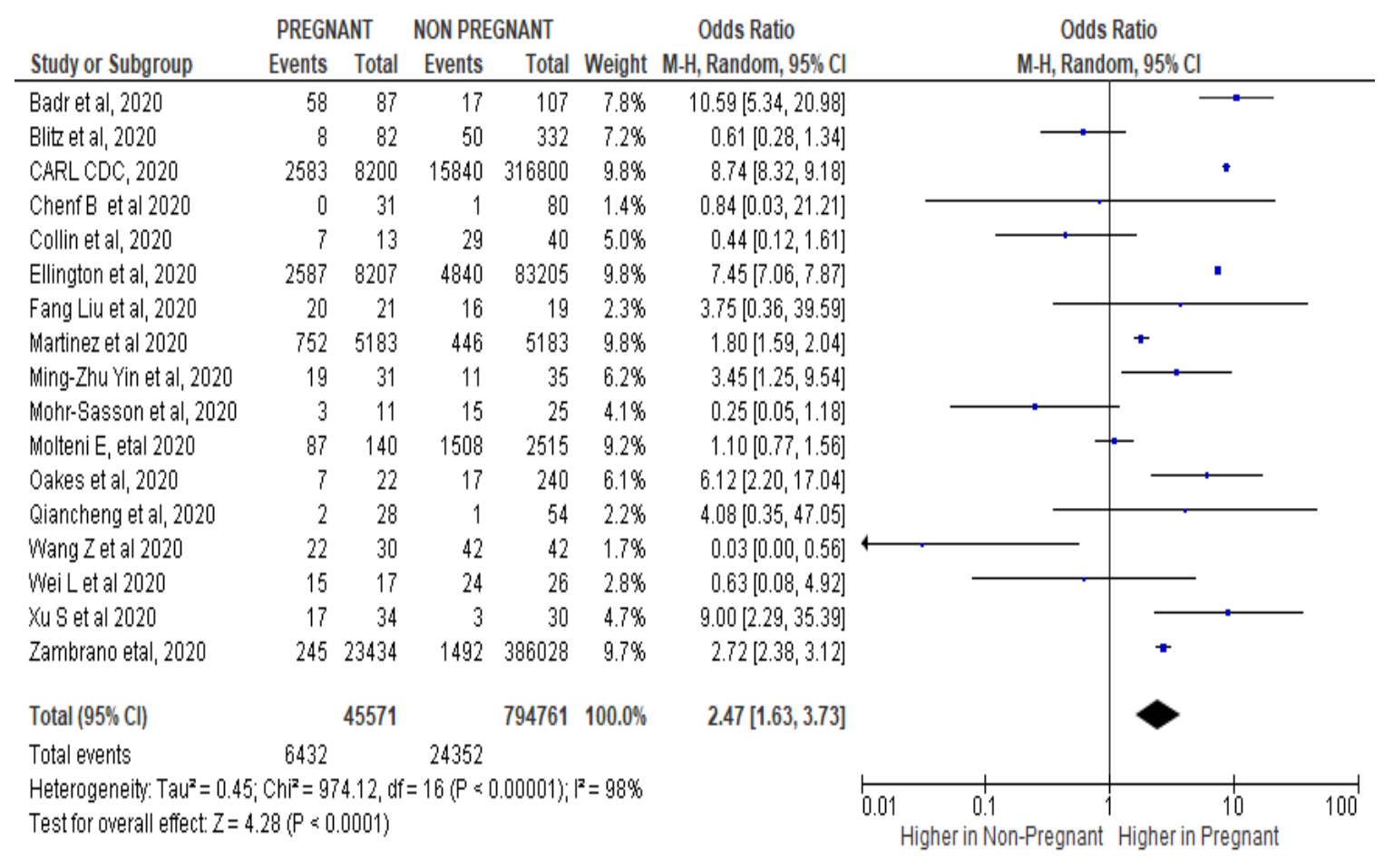

\section{Figure 2(a)}

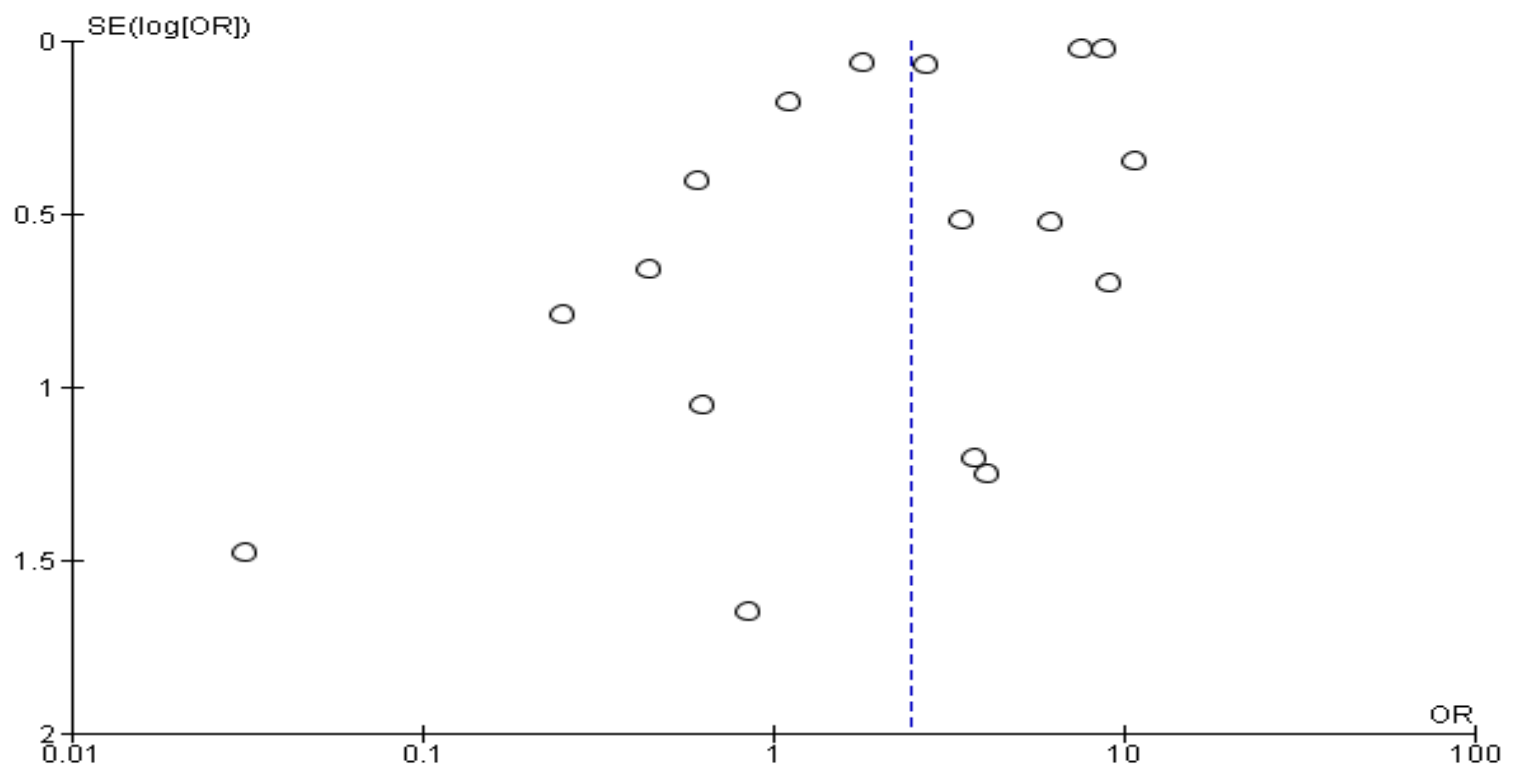

Figure 2(b) 
medRxiv preprint doi: https://doi.org/10.1101/2021.06.11.21258747; this version posted June 18, 2021. The copyright holder for this preprint (which was not certified by peer review) is the author/funder, who has granted medRxiv a license to display the preprint in perpetuity.

\section{It is made available under a CC-BY-NC-ND 4.0 International license .}

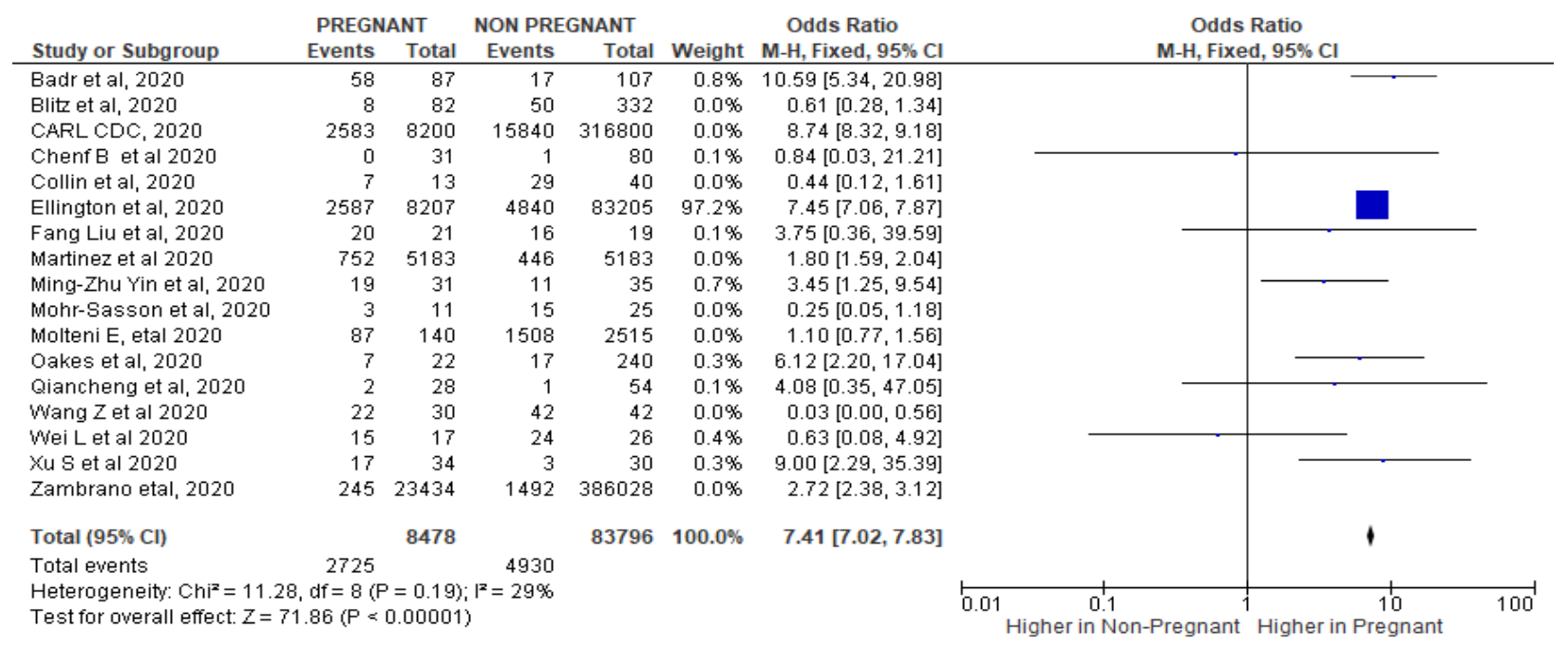

\section{Figure 2(c)}

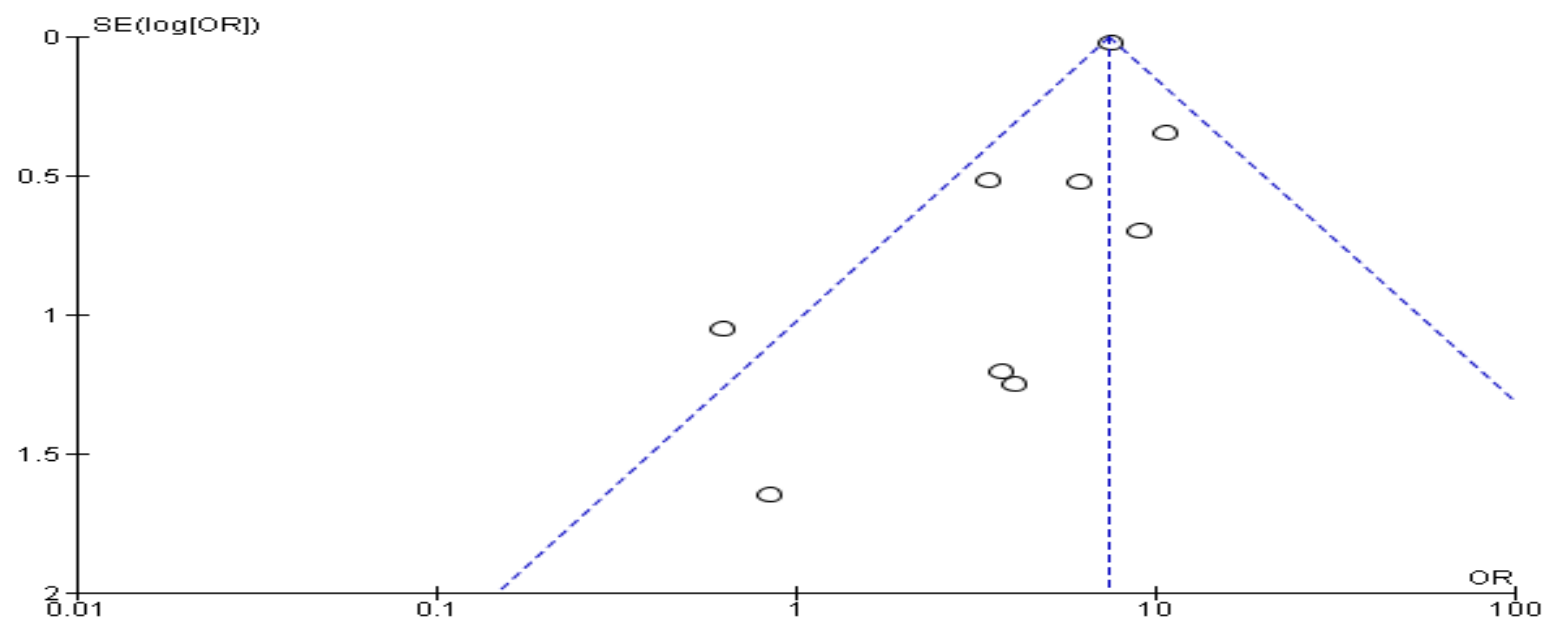

Figure 2(d)

\section{Figure 2}

(a) The cumulative incidence of severe COVID-19 characterized by Cytokine Storm. (b) Funnel plot for meta-analysis of cumulative incidence of severe COVID-19 characterized by Cytokine Storm. (c) The cumulative incidence of severe COVID-19 characterized by Cytokine Storm after excluding or including studies in meta-analysis based on sample size, methodological quality and variance. (d) Funnel plot for the meta-analysis of excluding or including studies in meta-analysis based on sample size, methodological quality and variance. 
medRxiv preprint doi: https://doi.org/10.1101/2021.06.11.21258747; this version posted June 18, 2021. The copyright holder for this preprint (which was not certified by peer review) is the author/funder, who has granted medRxiv a license to display the preprint in perpetuity.

It is made available under a CC-BY-NC-ND 4.0 International license .

\subsection{Subgroup analysis and investigation of heterogeneity}

Heterogeneity in the pooled effect estimates was considerably high in all the 17 studies and thus, it was necessary to perform subgroup analyses to identify possible variables or characteristics moderating the results obtained. This was done based on the number of Centers that the data was obtained from, as either Multiple Centre (MC) or single Centre studies (SC). The Subgroup Analysis demonstrated that, they were seemingly the same as heterogeneity was still quite high (I2 =72), Test for overall effect: $\mathrm{Z}=0.91(\mathrm{P}=0.36)$ and $(\mathrm{I} 2=98)$, Test for overall effect: $\mathrm{Z}=3.97(\mathrm{P}$ $<0.0001$ ) for $\mathrm{SC}$ and $\mathrm{MC}$ respectively both with $\mathrm{P}<0.00001$ with no significance difference (test for subgroup differences: $\left.\mathrm{Chi}^{2}=0.67, \mathrm{df}=1(\mathrm{P}=0.41), \mathrm{I}^{2}=0 \%\right)$ (Figures $3(\mathrm{a})$ and $3(\mathrm{~b})$. This prompted further sensitivity analysis on each subgroup to ascertain the group that mostly was associated with heterogeneity.

The sensitivity analysis on independent sub-analysis groups showed that Single Centre studies with the elimination of studies that were causing the major heterogeneity (Mohr-Sasson et al. [ ] and Wang $\mathrm{Z}$ et al. [ ], revealed that pregnancy was significantly related to severe COVID-19 with cytokine storm from single Centre studies, (fixed effect model, OR=3.97; 95\% CI: 2.26-6.95; $\mathrm{P}<$ $0.00001)$ with this updated analysis showing substantially very low heterogeneity $\left(I^{2}=2 \% ; P=\right.$ $0.42)$.

In regards to the Multiple Centre studies, subsequent removal of any study did not change the heterogeneity from its original (Heterogeneity: $\left.\mathrm{Chi}^{2}=928.90, \mathrm{df}=7(\mathrm{P}<0.00001) ; \mathrm{I}^{2}=99 \%\right)$, demonstrating that, Multiple Center studies were the main cause of heterogeneity and this was similar to the overall heterogeneity of the combined groups (Fixed effects model, Heterogeneity: $\left.\mathrm{Chi}^{2}=938.26, \mathrm{df}=14(\mathrm{P}<0.00001) ; \mathrm{I}^{2}=99 \%\right)$, with the test for subgroup differences being: $\mathrm{Chi}^{2}$ $\left.=1.9, \mathrm{df}=1(\mathrm{P}=0.17), \mathrm{I}^{2}=47.4 \%\right) \quad($ Figure $4(\mathrm{a}))$. The funnel plot similarly demonstrated that, MC studies were associated with heterogeneity with only one study forming part of homogeneity (Figure 4(a). 
medRxiv preprint doi: https://doi.org/10.1101/2021.06.11.21258747; this version posted June 18, 2021. The copyright holder for this preprint (which was not certified by peer review) is the author/funder, who has granted medRxiv a license to display the preprint in perpetuity.

It is made available under a CC-BY-NC-ND 4.0 International license.

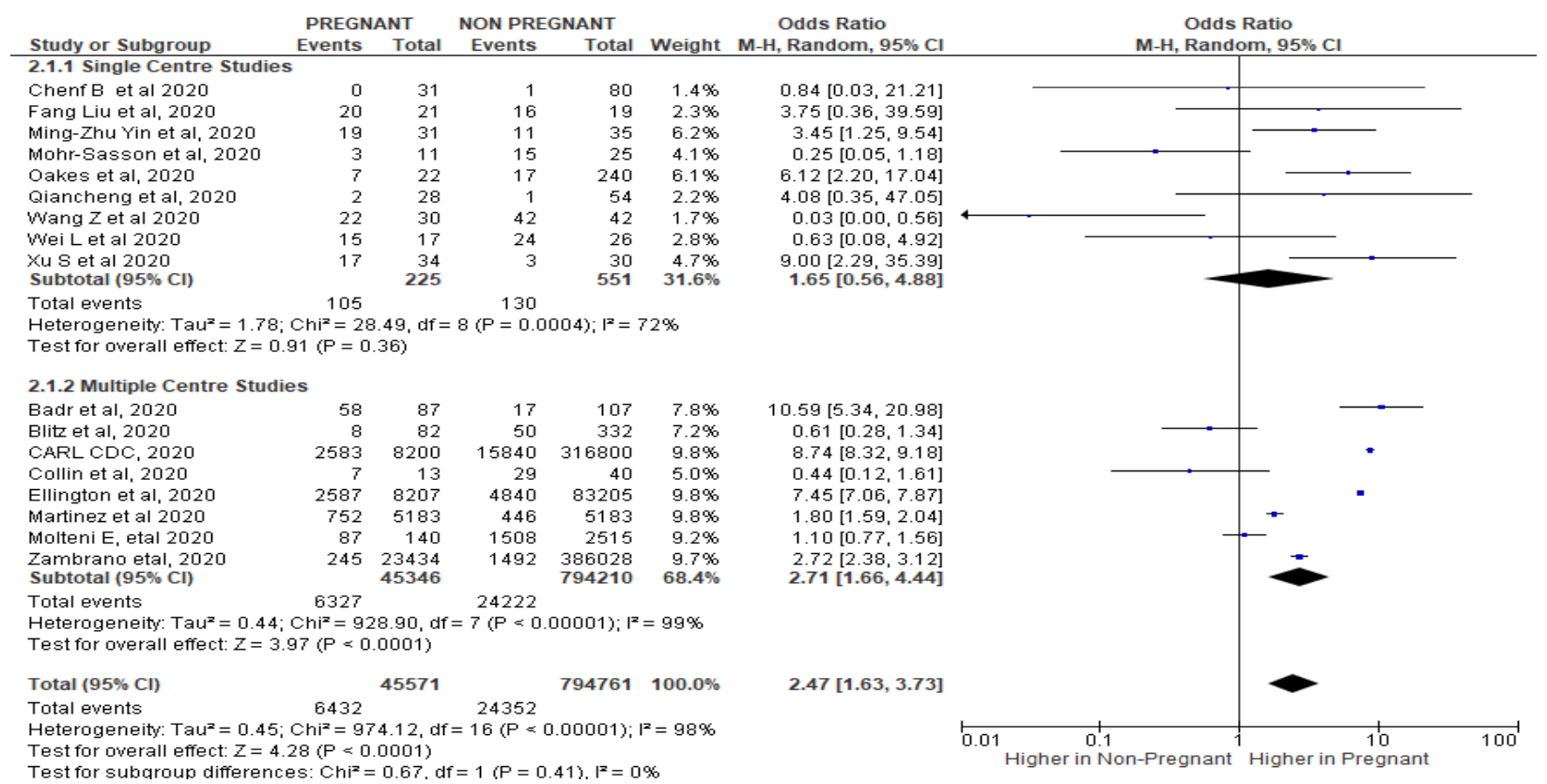

\section{Figure 3(a)}

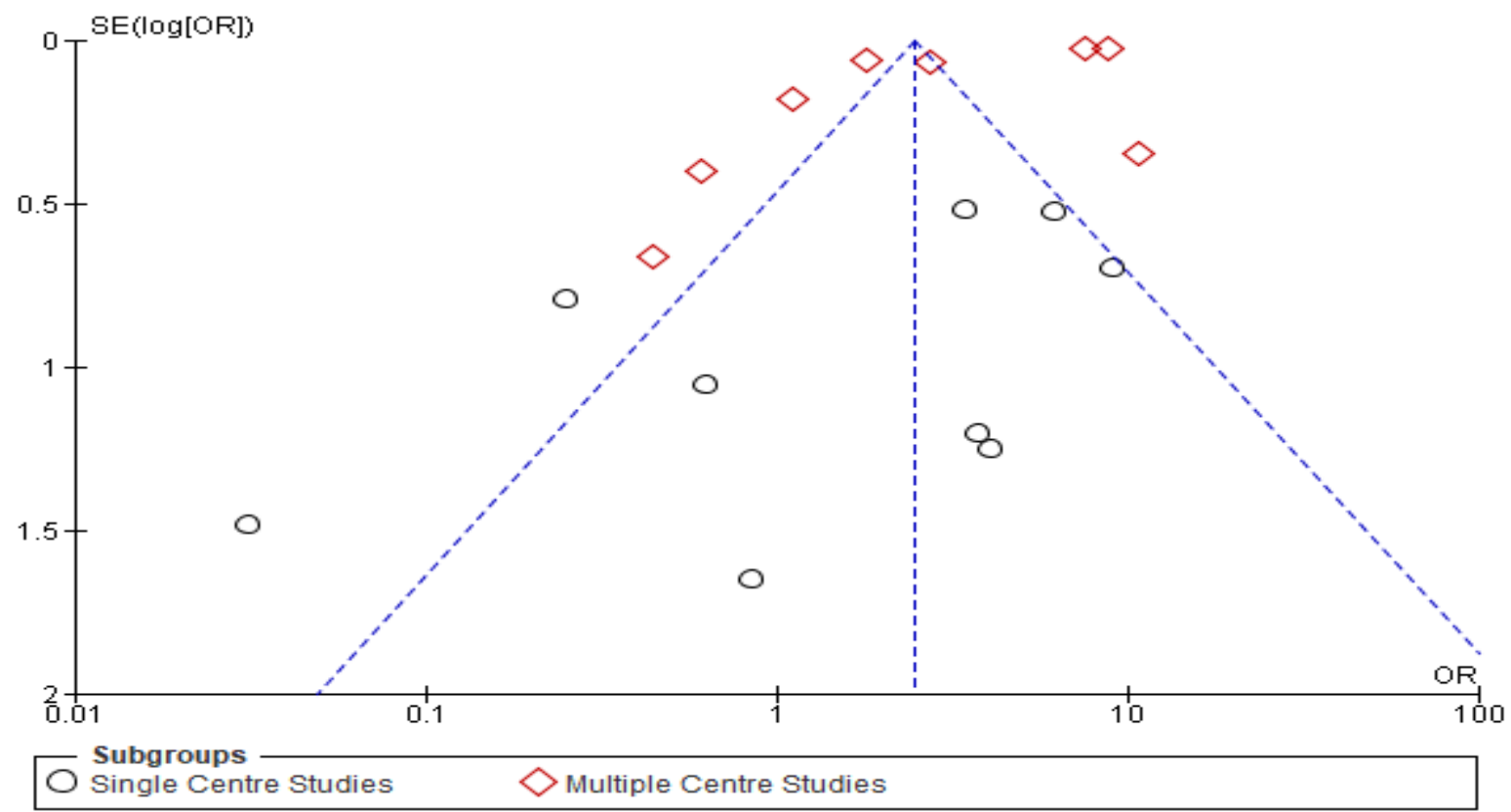

Figure 3(b)

\section{Figure 3}

(a) Subgroup analysis between Single Centre and Multiple Centre studies (b) Funnel plot for the meta-analysis of pregnancy and severe COVID-19 disease characterized by cytokine 
medRxiv preprint doi: https://doi.org/10.1101/2021.06.11.21258747; this version posted June 18, 2021. The copyright holder for this preprint (which was not certified by peer review) is the author/funder, who has granted medRxiv a license to display the preprint in perpetuity.

\section{It is made available under a CC-BY-NC-ND 4.0 International license .}

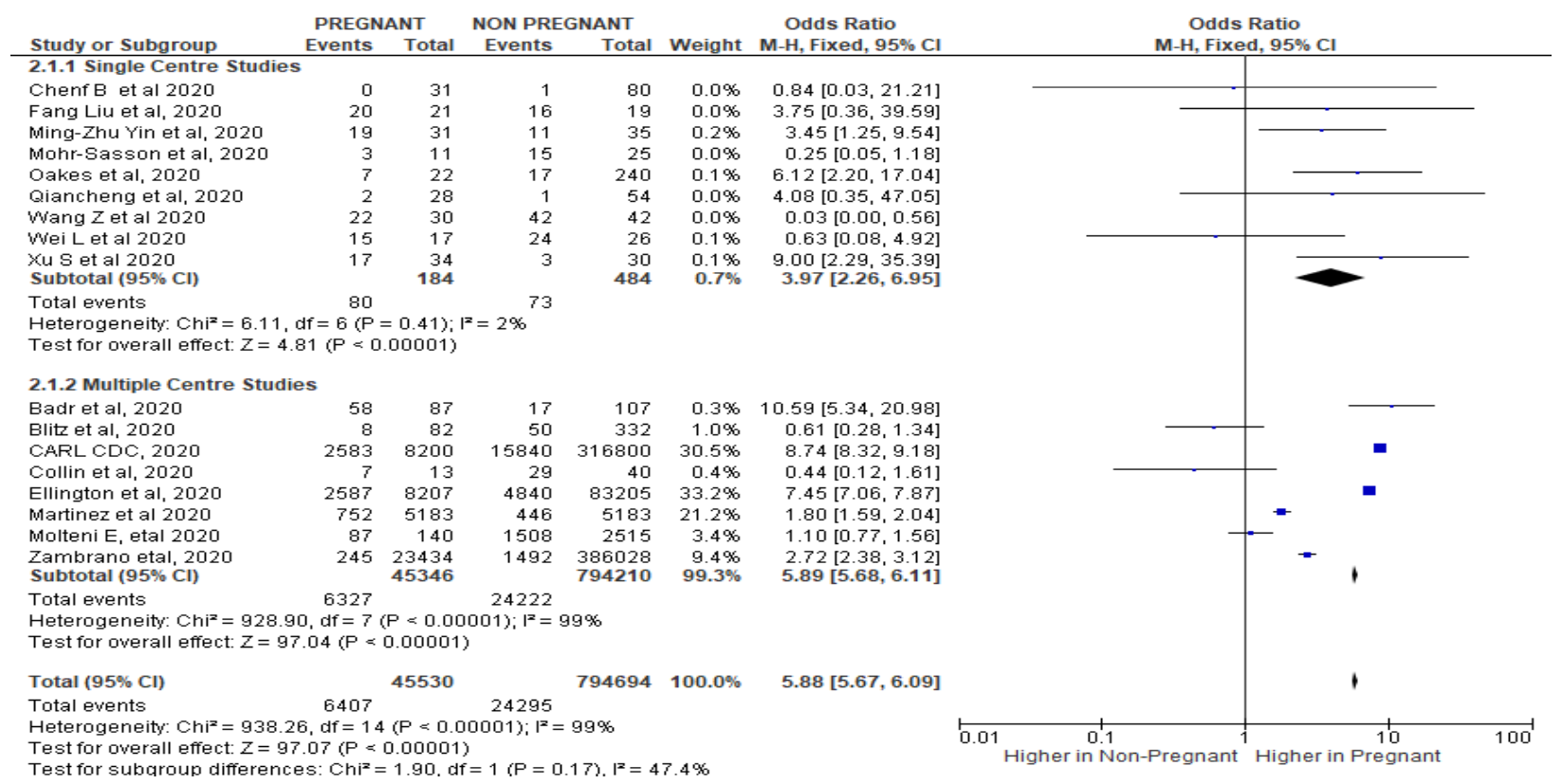

\section{Figure 4(a)}

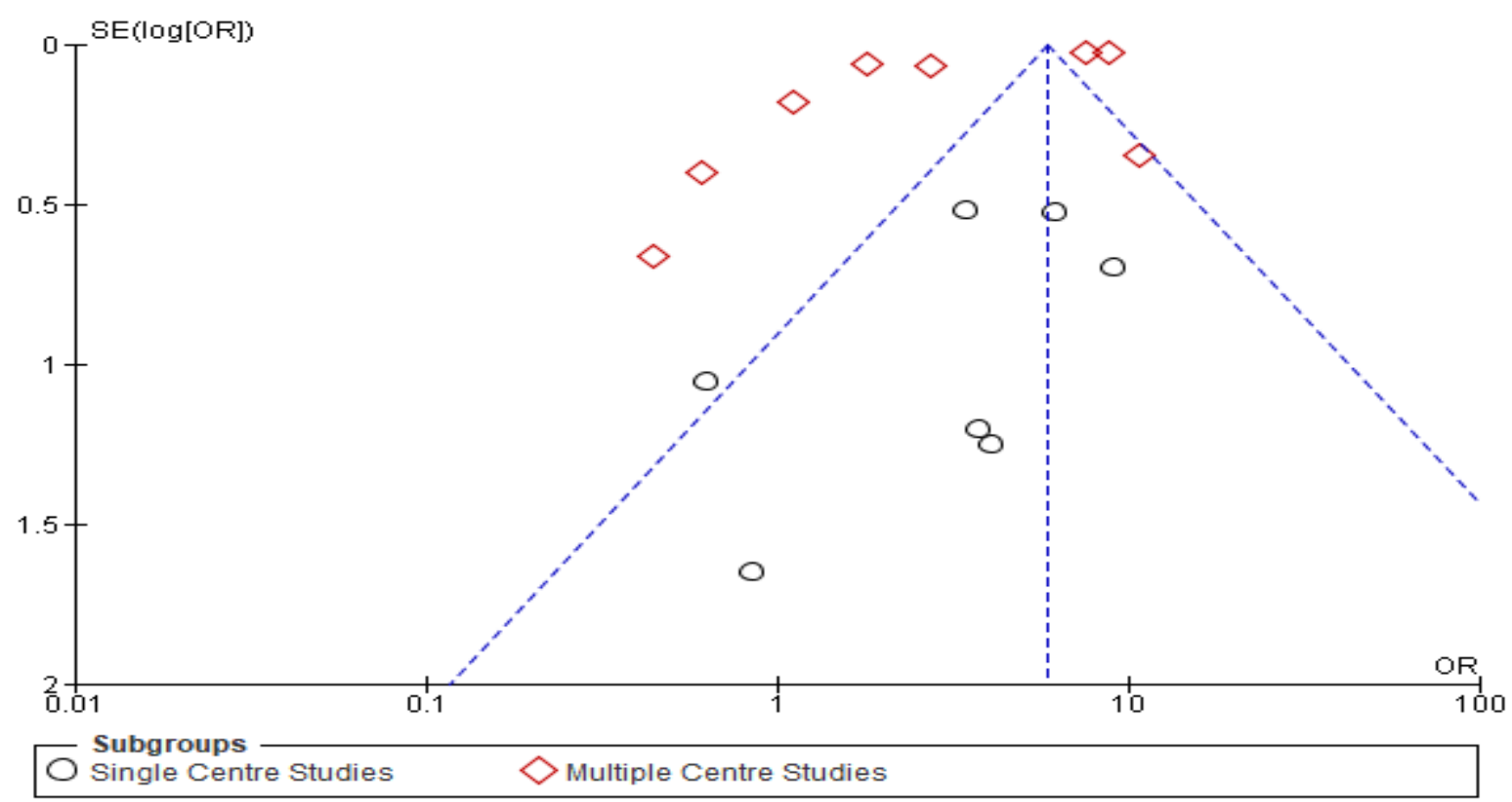

\section{Figure 4(b)}

\section{Figure 4}

(a) Comparison of specific subgroup analysis sensitivity testing between Single Centre and Multiple Centre studies in severe COVID-19 patients. (b) Funnel plot for the meta-analysis of pregnancy with severe COVID-19 disease between the subgroup analysis (Single Centre and Multiple Centre studies) 
medRxiv preprint doi: https://doi.org/10.1101/2021.06.11.21258747; this version posted June 18, 2021. The copyright holder for this preprint (which was not certified by peer review) is the author/funder, who has granted medRxiv a license to display the preprint in perpetuity. It is made available under a CC-BY-NC-ND 4.0 International license .

\section{Discussion}

The present meta-analysis contained 17 studies and revealed that pregnant women had significantly increased risk for severe COVID-19, characterized by a cytokine storm. Previous research has seemingly reported a similar result (Czeresnia et al., 2020; Kolkova et al., 2020). Additionally, one meta-analysis study has reported the outcome of coronavirus spectrum infections (SARS, MERS, and COVID-19) during pregnancy that, COVID-19 disease severity increased in gestation (Di Mascio et al., 2020). This analysis adds to the extensive consensus in the literature, invoking more studies and examining pregnancy status as a possible predictor of severe COVID19 characterized by a cytokine storm.

Prior studies have reported results that contrast with those presented here-namely, no significant difference between pregnant versus non-pregnant women diagnosed with COVID-19 in terms of its associated severity (Selim et al., 2020; Shankar \& KR, 2020; TIRMIKÇIOĞLU, 2021; TN \& RA, 2020). In addition, a meta-analysis conducted by Matar et al. (Matar et al., 2021) failed to find a relationship between being pregnant and severe COVID-19 24 studies including pregnant women, and another meta-analysis indicates that COVID-19 infection during pregnancy probably has a clinical presentation and severity resembling that in non-pregnant adults (Elshafeey et al., 2020). Also, a meta-analysis compared similar trends in severity between pregnant and the general population (Kasraeian et al., 2020). Further, two more studies showed no feasible differences in the clinical presentation of COVID-19 between pregnant and non-pregnant women (Jafari et al., 2021; Vaezi et al., 2021). Of concern, both meta-analyses (Elshafeey et al., 2020; Matar et al., 2021) included no assessment of publication bias or study quality. As such, it should be considered only a preliminary quest. Hence, the present systematic meta-analysis offers a more detailed view as it covers 17 studies from diverse regions capturing both single and multiple centers. The heterogeneity was high, and after sensitivity adjustments, the incidence of COVID - 19 severity with pregnancy was imminent with a substantially low heterogeneity after eliminating studies causing the same. Furthermore, the sub-group analysis after performing the sensitivity test in each specified subgroup (either MC or SC), there was a clear significant association between being pregnant and developing severe COVID-19 characterized by any specific parameter of cytokine storm evidenced in SC studies. Therefore, severe COVID-19 was observed almost 4 times $(\mathrm{OR}=$ 3.97; 95\% CI: 2.26-6.95; $\mathrm{P}<0.00001)$ more frequently in pregnant women. Some conducted 
medRxiv preprint doi: https://doi.org/10.1101/2021.06.11.21258747; this version posted June 18, 2021. The copyright holder for this preprint (which was not certified by peer review) is the author/funder, who has granted medRxiv a license to display the preprint in perpetuity. It is made available under a CC-BY-NC-ND 4.0 International license .

studies including some meta-analysis (Al-Matary et al., 2021; Galang et al., 2020; Grünebaum et al., 2021; Kasraeian et al., 2020; Lucarelli et al., 2020; Soheili et al., 2021; 2020 رنجبر \& قراجه, results have seemingly supported the current findings.

A recent meta-analysis revealed that SARSC-CoV-2 infection may not behave as mild as suggested during pregnancy (Barbero et al., 2020). Interestingly, this meta-analysis indicated that showed that 40 patients developed pneumonia, bilateral in most cases, with a $46.2 \%$ rate of hospitalization and 4 patients requiring intensive care unit (ICU) admission. The study found a higher rate of coronavirus disease (COVID-19) severe forms, even when compared to nonpregnant women with the same baseline characteristics (Barbero et al., 2020). This appears to be because pregnant women during the gestation period encounter a form of pro-inflammatory and inflammatory episodes which seem to mimic the trends of cytokine storm in Sever COVID-19 disease. This has been demonstrated in recent past studies (Cavalcante et al., 2021; Da Silva et al., 2020; Figuero et al., 2020; Malinowski et al., 2020). In addition, pregnancy has been reported to increase the progression of COVID-19 disease (Dashraath et al., 2020). There is growing evidence to support WHO's statements that pregnant women are at a higher risk of developing severe COVID-19 related symptoms and possible mortality (Blauvelt et al., 2020; Oganyan et al., 2020; Rashid et al., 2020; San-Juan et al., 2020). Again, pregnancy has been found to worsen the morbidity of COVID-19 and this effect becomes more prominent as pregnancy advances (Tug et al., 2020).

As it is of now, its somehow clear that postponing pregnancy during the pandemic period is imperative due to the possibility of encountering worse clinical outcomes and complications associated with pro-inflammatory and inflammatory cytokines creating synergy for severe COVID-19 cytokine storm(Ghi et al., 2020; Malinowski et al., 2020; Naidu et al., 2020).

The association between pregnancy and illness severity due to other respiratory viruses has been investigated previously. In one study, in pregnancy, the case fatality rate of $25 \%$, ICU admission $(50 \%)$, and mechanical ventilation (33\%), compared with the non-pregnant population (20\%) was experienced(Martens \& Kalgi, 2016), which may be implicated by immune responses in pregnancy. In addition, pregnancy may propagate respiratory infections and increase the risk of hospitalization (Lokken et al., 2021). A study also eluded that, complications of severity with 
medRxiv preprint doi: https://doi.org/10.1101/2021.06.11.21258747; this version posted June 18, 2021. The copyright holder for this preprint (which was not certified by peer review) is the author/funder, who has granted medRxiv a license to display the preprint in perpetuity. It is made available under a CC-BY-NC-ND 4.0 International license .

other SARD are enhanced in pregnancy (Wastnedge et al., 2021). As a result, adverse effects on the pregnant woman's lungs may aggravate the symptom severity of viral infections.

The novel SARS-CoV-2 uses an angiotensin-converting enzyme (ACE)-2 in the lungs to enter cells and cause infection. ACE2 expression and activity are enhanced during pregnancy, the transient ACE2 overexpression and increased activity during pregnancy may be important in modulating systemic, as well as local hemodynamics in the uteroplacental unit (Brosnihan et al., 2004; Levy et al., 2008). The ACE-2 upregulation may increase infectiousness and therefore infection severity risk, as the SARS-COV-2 virus uses this receptor for host entry. Paradoxically, it is stated that it may be useful in protecting people from acute lung injury (Pathangey et al., 2021).

In one recent study, ACE-2 gene expression was upregulated and widespread in specific (Li et al., 2020), thereby suggesting a mechanism by which risk for severe COVID-19 increases in pregnancy. The role of ACE2 in COVID-19 pathophysiology, including factors influencing ACE2 expression and activity in relation to COVID-19 severity, has been evidenced (Bourgonje et al., 2020), and thus, should be investigated for their potential impact on ACE-2 expression and thus SARS-COV-2 entry into the host and such, much focus in pregnancy (South et al., 2020).

Cytokine storm has received more attention because of the COVID-19 pandemic. Although we are learning more every day, cytokine storm seems to be at least part of the reason some people develop life-threatening symptoms from COVID-19, the medical condition caused by infection with SARS-CoV-2, and also, Hyper inflammatory cytokine storms in many severely symptomatic Covid-19 patients may be rooted in an atypical response to SARS-CoV-2 by the dysfunctional MCs of MCAS rather than a normal response by normal MCs (Afrin et al., 2020). This may be explained by systemic and chronic inflammation, diminished respiratory function and capacity, and COPD-related respiratory failure in some patients. There have been findings stipulating the association of pro-and anti-inflammatory cytokines which play crucial roles in the development and function of preeclampsia (Aggarwal et al., 2019). Given this, pregnancy itself and pro and inflammatory cytokines should be considered together as a single risk factor for severe COVID19 among pregnant women diagnosed with the novel coronavirus.

Another critical area of concern is that cytokine storms, which are seen in some severe COVID19 patients, are key causes of mortality in COVID-19. In these patients, pro-inflammatory cytokines such as interleukin (IL)-1, IL-2, IL-6, IL-8, IL-17, interferon- $\gamma$, and TNF- $\alpha$ are elevated, 
medRxiv preprint doi: https://doi.org/10.1101/2021.06.11.21258747; this version posted June 18, 2021. The copyright holder for this preprint (which was not certified by peer review) is the author/funder, who has granted medRxiv a license to display the preprint in perpetuity. It is made available under a CC-BY-NC-ND 4.0 International license .

which affect the patient's clinical symptoms and severity in the general population (McGonagle et al., 2020). In pregnancy, immune responses that are necessary to promote healthy pregnancy and those that lead to congenital disorders and pregnancy complications, with a particular emphasis on the role of interferons and cytokines are obvious (Yockey \& Iwasaki, 2018), some being similar to the ones activated during COVID-19 cytokine storms such as TNF- $\alpha$, IL-1 $\beta$, and IL-6 which are some of the fundamental cytokines that function in blastocyst implantation (Al Jameil et al., 2018). Therefore, increased levels of INF- $\gamma, \mathrm{LH}$, and prolactin having been identified as the underlying cause for recurrent pregnancy losses, therefore not only the severity amplification of cytokine storm of COVID-19 in pregnant women but consequential adverse pregnancy outcomes (Al Jameil et al., 2018). This potential interaction should be clarified with future clinical research, all the same.

Several factors limit the interpretation of the present study. First, the vast majority of studies included here were retrospective epidemiological studies conducted in the majorly USA and China, although with others from some different regions. Second, some included studies did not distinguish the age range of the participants as well as the stage of the gestation period. Third, CCVID 19 severity as assumed to be characterized by cytokine storm relied on different parameters of clinical implications such as; level of inflammatory cytokines, invasive mechanical ventilation, ICU admission, and such. Given these limitations, caution should be exercised while interpreting the current findings for more valid clinical practice. Future studies may respond to these issues by defining disease severity more clearly and by obtaining more detailed information on the associated inflammatory cytokines defining the COVID-19 cytokine storm.

Factors responsible for recurrent pregnancy loss are multiple and altered cytokine profile results in loss of pregnancy especially in the early stages of gestation. Similarly, exposure to high maternal pro-inflammatory cytokine concentrations in early pregnancy might play a part in several futuristic adverse effects on either the woman or the infant outcomes. With future studies, there is a need of the hour that women expecting a pregnancy must be screened to assess the cytokine profile even before conception to avoid loss of pregnancy and to improve the health and social well-being of the females as this may be aggravated in COVID-19 severity.

Finally, the interactions between the inherent inflammatory cytokines and cytokine storm due to COVID 19 should also be examined and clarified. In addition, clinicians can pay more attention 
medRxiv preprint doi: https://doi.org/10.1101/2021.06.11.21258747; this version posted June 18, 2021. The copyright holder for this preprint (which was not certified by peer review) is the author/funder, who has granted medRxiv a license to display the preprint in perpetuity.

It is made available under a CC-BY-NC-ND 4.0 International license .

to the history of pregnancy-related altered immune responses of COVID-19 patients, and more further research may aim to determine mechanisms that drive or decrease this risk of the severity by a 'within' the pregnant population study approach.

\section{Conclusion}

The present meta-analysis revealed that pregnancy is significantly associated with increased COVID-19 symptom severity defined by a cytokine storm. The SARS-COV-2 epidemic should serve as an impetus for pregnant women diagnosed with COVID-19, and map out salient risk factors associated with its severity with an aim of maintaining good health pregnancy outcome and possibly if at all, evade COVID-19 adverse clinical prognosis.

\section{Data Availability}

The data used to support the findings of this study are available from the corresponding author upon request.

\section{Conflicts of Interest}

The authors have stated explicitly that there are no conflicts of interest in connection with this article.

\section{Authors' Contributions}

JM performed the concept development of the manuscript, data collection, collation and retrieval, design of tables, images, and figures, major analysis and interpretation of data and reporting, and writing and drafting of the manuscript; KO performed the data collection and quality assessment; EN performed the acquisition of data, quality analysis, writing and revision of the manuscript; MK performed the major role in reviewing and revising the manuscript.

\section{Acknowledgments}

Funding of the Kenya Medical Training College for the execution of this study is gratefully acknowledged.

\section{References}

Afrin, L. B., Weinstock, L. B., \& Molderings, G. J. (2020). Covid-19 hyperinflammation and postCovid-19 illness may be rooted in mast cell activation syndrome. In International Journal of 
medRxiv preprint doi: https://doi.org/10.1101/2021.06.11.21258747; this version posted June 18, 2021. The copyright holder for this preprint (which was not certified by peer review) is the author/funder, who has granted medRxiv a license to display the preprint in perpetuity. It is made available under a CC-BY-NC-ND 4.0 International license .

Infectious Diseases (Vol. 100). https://doi.org/10.1016/j.ijid.2020.09.016

Aggarwal, R., Jain, A. K., Mittal, P., Kohli, M., Jawanjal, P., \& Rath, G. (2019). Association of pro- and anti-inflammatory cytokines in preeclampsia. Journal of Clinical Laboratory Analysis, 33(4). https://doi.org/10.1002/jcla.22834

Al-Matary, A., Almatari, F., Al-Matary, M., AlDhaefi, A., Alqahtani, M. H. S., Alhulaimi, E. A., AlOtaiby, S., Almehiny, K., John, L. S., Alanazi, F. S., Ali, A. M., \& Aldandan, F. K. (2021). Clinical outcomes of maternal and neonate with COVID-19 infection - Multicenter study in Saudi Arabia. Journal of Infection and Public Health, 14(6). https://doi.org/10.1016/j.jiph.2021.03.013

Al Jameil, N., Tabassum, H., AlMayouf, H., Alshenefy, A., Almohizea, M. M., \& Ali, M. N. (2018). Identification of serum cytokines as markers in women with recurrent pregnancy loss or miscarriage using MILLIPLEX analysis. Biomedical Research (India), 29(18). https://doi.org/10.4066/biomedicalresearch.29-18-1030

Badr, D. A., Mattern, J., Carlin, A., Cordier, A. G., Maillart, E., El Hachem, L., El Kenz, H., Andronikof, M., De Bels, D., Damoisel, C., Preseau, T., Vignes, D., Cannie, M. M., VauloupFellous, C., Fils, J. F., Benachi, A., Jani, J. C., \& Vivanti, A. J. (2020). Are clinical outcomes worse for pregnant women at $\geq 20$ weeks' gestation infected with coronavirus disease 2019 ? A multicenter case-control study with propensity score matching. In American Journal of Obstetrics and Gynecology (Vol. 223, Issue 5). https://doi.org/10.1016/j.ajog.2020.07.045

Barbero, P., Mugüerza, L., Herraiz, I., García Burguillo, A., San Juan, R., Forcén, L., Mejía, I., Batllori, E., Montañez, M. D., Vallejo, P., Villar, O., García Alcazar, D., \& Galindo, A. (2020). SARS-CoV-2 in pregnancy: characteristics and outcomes of hospitalized and nonhospitalized women due to COVID-19. Journal of Maternal-Fetal and Neonatal Medicine. https://doi.org/10.1080/14767058.2020.1793320

Barile, L., Cerrano, M., Locatelli, A., Puppo, A., Signorile, A. F., \& Barzaghi, N. (2020). Prone ventilation in a 27 week pregnant woman with COVID-19 severe ards. Signa Vitae, 16(1). https://doi.org/10.22514/sv.2020.16.0028

Bhaskar, S., Sinha, A., Banach, M., Mittoo, S., Weissert, R., Kass, J. S., Rajagopal, S., Pai, A. R., \& Kutty, S. (2020). Cytokine Storm in COVID-19-Immunopathological Mechanisms, Clinical Considerations, and Therapeutic Approaches: The REPROGRAM Consortium Position Paper. Frontiers in Immunology, 11. https://doi.org/10.3389/fimmu.2020.01648

Blauvelt, C. A., Chiu, C., Donovan, A. L., Prahl, M., Shimotake, T. K., George, R. B., Schwartz, B. S., Farooqi, N. A., Ali, S. S., Cassidy, A., Gonzalez, J. M., \& Gaw, S. L. (2020). Acute Respiratory Distress Syndrome in a Preterm Pregnant Patient with Coronavirus Disease 2019 (COVID-19). Obstetrics and Gynecology, 136(1). https://doi.org/10.1097/AOG.0000000000003949 
medRxiv preprint doi: https://doi.org/10.1101/2021.06.11.21258747; this version posted June 18, 2021. The copyright holder for this preprint

(which was not certified by peer review) is the author/funder, who has granted medRxiv a license to display the preprint in perpetuity. It is made available under a CC-BY-NC-ND 4.0 International license .

Blitz, M. J., Grünebaum, A., Tekbali, A., Bornstein, E., Rochelson, B., Nimaroff, M., \& Chervenak, F. A. (2020). Intensive care unit admissions for pregnant and nonpregnant women with coronavirus disease 2019. In American Journal of Obstetrics and Gynecology (Vol. 223, Issue 2). https://doi.org/10.1016/j.ajog.2020.05.004

Bourgonje, A. R., Abdulle, A. E., Timens, W., Hillebrands, J. L., Navis, G. J., Gordijn, S. J., Bolling, M. C., Dijkstra, G., Voors, A. A., Osterhaus, A. D. M. E., van der Voort, P. H. J., Mulder, D. J., \& van Goor, H. (2020). Angiotensin-converting enzyme 2 (ACE2), SARSCoV-2 and the pathophysiology of coronavirus disease 2019 (COVID-19). In Journal of Pathology (Vol. 251, Issue 3). https://doi.org/10.1002/path.5471

Brosnihan, K. B., Neves, L. A. A., Anton, L., Joyner, J., Valdes, G., \& Merrill, D. C. (2004). Enhanced expression of Ang-(1-7) during pregnancy. Brazilian Journal of Medical and Biological Research, 37(8). https://doi.org/10.1590/S0100-879X2004000800017

Cavalcante, M. B., Cavalcante, C. T. de M. B., Sarno, M., Barini, R., \& Kwak-Kim, J. (2021). Maternal immune responses and obstetrical outcomes of pregnant women with COVID-19 and possible health risks of offspring. In Journal of Reproductive Immunology (Vol. 143). https://doi.org/10.1016/j.jri.2020.103250

Centers for Disease Control and Prevention. (2020). Assessing Risk Factors for Severe COVID-19 Illness. Assessing Risk Factors for Severe COVID-19 Illness.

Chen, L., Jiang, H., \& Zhao, Y. (2020). Pregnancy with COVID-19: Management considerations for care of severe and critically ill cases. American Journal of Reproductive Immunology, 84(5). https://doi.org/10.1111/aji.13299

Cheng, B., Jiang, T., Zhang, L., Hu, R., Tian, J., Jiang, Y., Huang, B., Li, J., Wei, M., Yang, J., Ren, S., \& Wang, G. (2020). Clinical characteristics of pregnant women with coronavirus disease 2019 in Wuhan, China. Open Forum Infectious Diseases, 7(8). https://doi.org/10.1093/ofid/ofaa294

Chow, N., Fleming-Dutra, K., Gierke, R., Hall, A., Hughes, M., Pilishvili, T., Ritchey, M., Roguski, K., Skoff, T., \& Ussery, E. (2020). Preliminary Estimates of the Prevalence of Selected Underlying Health Conditions Among Patients with COVID-19 - US, February 12March 28, 2020. MMWR Morbidity and Mortality Weekly Report, 69(13).

Collin, J., Byström, E., Carnahan, A. S., \& Ahrne, M. (2020). Public Health Agency of Sweden's Brief Report: Pregnant and postpartum women with severe acute respiratory syndrome coronavirus 2 infection in intensive care in Sweden. Acta Obstetricia et Gynecologica Scandinavica, 99(7). https://doi.org/10.1111/aogs.13901

Czeresnia, R. M., Trad, A. T. A., Britto, I. S. W., Negrini, R., Nomura, M. L., Pires, P., Costa, F. da S., Nomura, R. M. Y., \& Ruano, R. (2020). SARS-CoV-2 e gestação: uma revisão dos fatos TT - SARS-CoV-2 and Pregnancy: A Review of the Facts. Rev Bras Ginecol Obstet, 
medRxiv preprint doi: https://doi.org/10.1101/2021.06.11.21258747; this version posted June 18, 2021. The copyright holder for this preprint (which was not certified by peer review) is the author/funder, who has granted medRxiv a license to display the preprint in perpetuity. It is made available under a CC-BY-NC-ND 4.0 International license .

42(9).

Da Silva, C. R. A. C., De Oliveira, L. V., Lopes, L. P., Dos Santos, W. A. G., \& Agra, I. K. R. (2020). Immunological aspects of coronavirus disease during pregnancy: An integrative review. Revista Da Associacao Medica Brasileira, 66(5). https://doi.org/10.1590/18069282.66.5.696

Dashraath, P., Wong, J. L. J., Lim, M. X. K., Lim, L. M., Li, S., Biswas, A., Choolani, M., Mattar, C., \& Su, L. L. (2020). Coronavirus disease 2019 (COVID-19) pandemic and pregnancy. American Journal of Obstetrics and Gynecology, 222(6). https://doi.org/10.1016/j.ajog.2020.03.021

Di Mascio, D., Khalil, A., Saccone, G., Rizzo, G., Buca, D., Liberati, M., Vecchiet, J., Nappi, L., Scambia, G., Berghella, V., \& D'Antonio, F. (2020). Outcome of coronavirus spectrum infections (SARS, MERS, COVID-19) during pregnancy: a systematic review and metaanalysis. American Journal of Obstetrics \& Gynecology MFM, 2(2). https://doi.org/10.1016/j.ajogmf.2020.100107

Ellington, S., Strid, P., Tong, V. T., Woodworth, K., Galang, R. R., Zambrano, L. D., Nahabedian, J., Anderson, K., \& Gilboa, S. M. (2020). Characteristics of Women of Reproductive Age with Laboratory-Confirmed SARS-CoV-2 Infection by Pregnancy Status - United States, January 22-June 7, 2020. MMWR. Morbidity and Mortality Weekly Report, 69(25). https://doi.org/10.15585/mmwr.mm6925a1

Elshafeey, F., Magdi, R., Hindi, N., Elshebiny, M., Farrag, N., Mahdy, S., Sabbour, M., Gebril, S., Nasser, M., Kamel, M., Amir, A., Maher Emara, M., \& Nabhan, A. (2020). A systematic scoping review of COVID-19 during pregnancy and childbirth. In International Journal of Gynecology and Obstetrics (Vol. 150, Issue 1). https://doi.org/10.1002/ijgo.13182

Figuero, E., Han, Y. W., \& Furuichi, Y. (2020). Periodontal diseases and adverse pregnancy outcomes: Mechanisms. In Periodontology 2000 (Vol. 83, Issue 1). https://doi.org/10.1111/prd.12295

Galang, R. R., Chang, K., Strid, P., Snead, M. C., Woodworth, K. R., House, L. D., Perez, M., Barfield, W. D., Meaney-Delman, D., Jamieson, D. J., Shapiro-Mendoza, C. K., \& Ellington, S. R. (2020). Severe coronavirus infections in pregnancy: A systematic review. In Obstetrics and Gynecology (Vol. 136, Issue 2). https://doi.org/10.1097/AOG.0000000000004011

Garg, S., Kim, L., Whitaker, M., O’Halloran, A., Cummings, C., Holstein, R., Prill, M., Chai, S. J., Kirley, P. D., Alden, N. B., Kawasaki, B., Yousey-Hindes, K., Niccolai, L., Anderson, E. J., Openo, K. P., Weigel, A., Monroe, M. L., Ryan, P., Henderson, J., .. Fry, A. (2020). Hospitalization Rates and Characteristics of Patients Hospitalized with LaboratoryConfirmed Coronavirus Disease 2019 - COVID-NET, 14 States, March 1-30, 2020. MMWR. Morbidity and Mortality Weekly Report, 69(15). 
medRxiv preprint doi: https://doi.org/10.1101/2021.06.11.21258747; this version posted June 18, 2021. The copyright holder for this preprint (which was not certified by peer review) is the author/funder, who has granted medRxiv a license to display the preprint in perpetuity. It is made available under a CC-BY-NC-ND 4.0 International license .

https://doi.org/10.15585/mmwr.mm6915e3

Gerasimov, A., Lebedev, G., Lebedev, M., \& Semenycheva, I. (2020). COVID-19 dynamics: A heterogeneous model. In medRxiv. https://doi.org/10.1101/2020.05.04.20090688

Ghi, T., di Pasquo, E., Mekinian, A., Calza, L., \& Frusca, T. (2020). Sars-CoV-2 in pregnancy: Why is it better than expected? In European Journal of Obstetrics and Gynecology and Reproductive Biology (Vol. 252). https://doi.org/10.1016/j.ejogrb.2020.07.025

Grünebaum, A., McCullough, L. B., Litvak, A., \& Chervenak, F. A. (2021). Inclusion of pregnant individuals among priority populations for coronavirus disease 2019 vaccination for all 50 states in the United States. American Journal of Obstetrics and Gynecology, 224(5). https://doi.org/10.1016/j.ajog.2021.01.026

Handayani, D., Hadi, D. R., Isbaniah, F., Burhan, E., \& Agustin, H. (2020). Corona Virus Disease 2019. Jurnal Respirologi Indonesia, 40(2). https://doi.org/10.36497/jri.v40i2.101

Hu, B., Huang, S., \& Yin, L. (2021). The cytokine storm and COVID-19. In Journal of Medical Virology (Vol. 93, Issue 1). https://doi.org/10.1002/jmv.26232

Jafari, M., Pormohammad, A., Sheikh Neshin, S. A., Ghorbani, S., Bose, D., Alimohammadi, S., Basirjafari, S., Mohammadi, M., Rasmussen-Ivey, C., Razizadeh, M. H., Nouri-Vaskeh, M., \& Zarei, M. (2021). Clinical characteristics and outcomes of pregnant women with COVID19 and comparison with control patients: A systematic review and meta-analysis. In Reviews in Medical Virology. https://doi.org/10.1002/rmv.2208

Kasraeian, M., Zare, M., Vafaei, H., Asadi, N., Faraji, A., Bazrafshan, K., \& Roozmeh, S. (2020). COVID-19 pneumonia and pregnancy; a systematic review and meta-analysis. Journal of Maternal-Fetal and Neonatal Medicine. https://doi.org/10.1080/14767058.2020.1763952

Kolkova, Z., Bjurström, M. F., Länsberg, J. K., Svedas, E., Hamer, M. A., Hansson, S. R., Herbst, A., \& Zaigham, M. (2020). Obstetric and intensive-care strategies in a high-risk pregnancy with critical respiratory failure due to COVID-19: A case report. Case Reports in Women's Health, 27. https://doi.org/10.1016/j.crwh.2020.e00240

Levy, A., Yagil, Y., Bursztyn, M., Barkalifa, R., Scharf, S., \& Yagil, C. (2008). ACE2 expression and activity are enhanced during pregnancy. American Journal of Physiology - Regulatory Integrative and Comparative Physiology, 295(6). https://doi.org/10.1152/ajpregu.90592.2008

Li, M., Chen, L., Zhang, J., Xiong, C., \& Li, X. (2020). The SARS-CoV-2 receptor ACE2 expression of maternal-fetal interface and fetal organs by single-cell transcriptome study. PLoS ONE, 15(4). https://doi.org/10.1371/journal.pone.0230295

Liu, F., Liu, H., Hou, L., Li, J., Zheng, H., Chi, R., Lan, W., \& Wang, D. (2020). Clinicoradiological features and outcomes in pregnant women with COVID-19 pneumonia compared 
medRxiv preprint doi: https://doi.org/10.1101/2021.06.11.21258747; this version posted June 18, 2021. The copyright holder for this preprint (which was not certified by peer review) is the author/funder, who has granted medRxiv a license to display the preprint in perpetuity. It is made available under a CC-BY-NC-ND 4.0 International license .

with age-matched non-pregnant women. Infection and Drug Resistance, 13. https://doi.org/10.2147/IDR.S264541

Lokken, E. M., Taylor, G. G., Huebner, E. M., Vanderhoeven, J., Hendrickson, S., Coler, B., Sheng, J. S., Walker, C. L., McCartney, S. A., Kretzer, N. M., Resnick, R., Kachikis, A., Barnhart, N., Schulte, V., Bergam, B., Ma, K. K., Albright, C., Larios, V., Kelley, L., ... Adams Waldorf, K. M. (2021). Higher severe acute respiratory syndrome coronavirus 2 infection rate in pregnant patients. American Journal of Obstetrics and Gynecology. https://doi.org/10.1016/j.ajog.2021.02.011

Lucarelli, E., Behn, C., Lashley, S., Smok, D., Benito, C., \& Oyelese, Y. (2020). Mechanical Ventilation in Pregnancy Due to COVID-19: A Cohort of Three Cases. American Journal of Perinatology, 37(10). https://doi.org/10.1055/s-0040-1713664

Malinowski, A. K., Noureldin, A., \& Othman, M. (2020). COVID-19 susceptibility in pregnancy: Immune/inflammatory considerations, the role of placental ACE-2 and research considerations. Reproductive Biology, 20(4). https://doi.org/10.1016/j.repbio.2020.10.005

Martens, M., \& Kalgi, B. (2016). Middle Eastern Respiratory Syndrome and Pregnancy [18J]. $\begin{array}{lllll}\text { Obstetrics } \quad \& \quad \text { Gynecology, } & \text { 127(Supplement } & 1 \text { ). }\end{array}$ https://doi.org/10.1097/01.aog.0000483787.93122.d5

Martinez-Portilla, R. J., Sotiriadis, A., Chatzakis, C., Torres-Torres, J., Espino y Sosa, S., Sandoval-Mandujano, K., Castro-Bernabe, D. A., Medina-Jimenez, V., Monarrez-Martin, J. C., Figueras, F., \& Poon, L. C. (2021). Pregnant women with SARS-CoV-2 infection are at higher risk of death and pneumonia: propensity score matched analysis of a nationwide prospective cohort (COV19Mx). Ultrasound in Obstetrics and Gynecology, 57(2). https://doi.org/10.1002/uog.23575

Matar, R., Alrahmani, L., Monzer, N., Debiane, L. G., Berbari, E., Fares, J., Fitzpatrick, F., \& Murad, M. H. (2021). Clinical Presentation and Outcomes of Pregnant Women with Coronavirus Disease 2019: A Systematic Review and Meta-analysis. In Clinical Infectious Diseases (Vol. 72, Issue 3). https://doi.org/10.1093/cid/ciaa828

McGonagle, D., Sharif, K., O’Regan, A., \& Bridgewood, C. (2020). The Role of Cytokines including Interleukin-6 in COVID-19 induced Pneumonia and Macrophage Activation Syndrome-Like Disease. In Autoimmunity Reviews (Vol. 19, Issue 6). https://doi.org/10.1016/j.autrev.2020.102537

Moher, D., Shamseer, L., Clarke, M., Ghersi, D., Liberati, A., Petticrew, M., Shekelle, P., Stewart, L. A., Estarli, M., Barrera, E. S. A., Martínez-Rodríguez, R., Baladia, E., Agüero, S. D., Camacho, S., Buhring, K., Herrero-López, A., Gil-González, D. M., Altman, D. G., Booth, A., ... Whitlock, E. (2016). Preferred reporting items for systematic review and meta-analysis protocols (PRISMA-P) 2015 statement. Revista Espanola de Nutricion Humana y Dietetica, 
medRxiv preprint doi: https://doi.org/10.1101/2021.06.11.21258747; this version posted June 18, 2021. The copyright holder for this preprint

(which was not certified by peer review) is the author/funder, who has granted medRxiv a license to display the preprint in perpetuity. It is made available under a CC-BY-NC-ND 4.0 International license .

20(2). https://doi.org/10.1186/2046-4053-4-1

Mohr-Sasson, A., Chayo, J., Bart, Y., Meyer, R., Sivan, E., Mazaki-Tovi, S., \& Yinon, Y. (2020). Laboratory characteristics of pregnant compared to non-pregnant women infected with SARS-CoV-2. Archives of Gynecology and Obstetrics, 302(3). https://doi.org/10.1007/s00404-020-05655-7

Molteni, E., Astley, C. M., Ma, W., Sudre, C. H., Magee, L. A., Murray, B., Fall, T., Gomez, M. F., Tsereteli, N., Franks, P. W., Brownstein, J. S., Davies, R., Wolf, J., Spector, T. D., Ourselin, S., Steves, C. J., Chan, A. T., \& Modat, M. (2020). SARS-CoV-2 (COVID-19) infection in pregnant women: Characterization of symptoms and syndromes predictive of disease and severity through real-time, remote participatory epidemiology. In medRxiv. https://doi.org/10.1101/2020.08.17.20161760

Naidu, S. A. G., Clemens, R. A., Pressman, P., Zaigham, M., Kadkhoda, K., Davies, K. J. A., \& Naidu, A. S. (2020). COVID-19 during Pregnancy and Postpartum: Journal of Dietary Supplements. https://doi.org/10.1080/19390211.2020.1834049

Oakes, M. C., Kernberg, A. S., Carter, E. B., Foeller, M. E., Palanisamy, A., Raghuraman, N., \& Kelly, J. C. (2021). Pregnancy as a risk factor for severe coronavirus disease 2019 using standardized clinical criteria. American Journal of Obstetrics \& Gynecology MFM, 3(3). https://doi.org/10.1016/j.ajogmf.2021.100319

Oganyan, K. A., Shalepo, K. V., Savicheva, A. M., Bespalova, O. N., \& Kogan, I. Y. (2020). NEW CORONAVIRUS INFECTION and PREGNANCY. Journal of Obstetrics and Women's Diseases, 69(6). https://doi.org/10.17816/JOWD69671-80

Pathangey, G., Fadadu, P. P., Hospodar, A. R., \& Abbas, A. E. (2021). Angiotensin-converting enzyme 2 and COVID-19: Patients, comorbidities, and therapies. In American Journal of Physiology - Lung Cellular and Molecular Physiology (Vol. 320, Issue 3). https://doi.org/10.1152/AJPLUNG.00259.2020

Qiancheng, X., Jian, S., Lingling, P., Lei, H., Xiaogan, J., Weihua, L., Gang, Y., Shirong, L., Zhen, W., GuoPing, X., \& Lei, Z. (2020). Coronavirus disease 2019 in pregnancy. International Journal of Infectious Diseases, 95. https://doi.org/10.1016/j.ijid.2020.04.065

Rashid, F., Shahnaz, S., Sharmin, R., Sattar, M. A., \& Chowdhury, S. (2020). Pregnancy with COVID-19: Weal and woe. Journal of SAFOG, 12(4). https://doi.org/10.5005/jp-journals10006-1798

San-Juan, R., Barbero, P., Fernández-Ruiz, M., López-Medrano, F., Lizasoáin, M., HernándezJiménez, P., Silva, J. T., Ruiz-Ruigómez, M., Corbella, L., Rodríguez-Goncer, I., Folgueira, M. D., Lalueza, A., Batllori, E., Mejía, I., Forcén, L., Lumbreras, C., García-Burguillo, A., Galindo, A., \& Aguado, J. M. (2020). Incidence and clinical profiles of COVID-19 pneumonia in pregnant women: A single-centre cohort study from Spain. EClinicalMedicine, 
medRxiv preprint doi: https://doi.org/10.1101/2021.06.11.21258747; this version posted June 18, 2021. The copyright holder for this preprint (which was not certified by peer review) is the author/funder, who has granted medRxiv a license to display the preprint in perpetuity. It is made available under a CC-BY-NC-ND 4.0 International license .

23. https://doi.org/10.1016/j.eclinm.2020.100407

Selim, M., Mohamed, S., Abdo, M., \& Abdelhaffez, A. (2020). Is COVID-19 Similar in Pregnant and Non-Pregnant Women? Cureus. https://doi.org/10.7759/cureus.8888

Shankar, M., \& KR, N. (2020). Pregnancy and Coronavirus Disease 19. Integrative Journal of Medical Sciences, 7. https://doi.org/10.15342/ijms.7.195

Sharma, A. K. (2020). Novel Coronavirus Disease (COVID-19). Resonance, 25(5). https://doi.org/10.1007/s12045-020-0981-3

Soheili, M., Moradi, G., Baradaran, H. R., Soheili, M., Mokhtari, M. M., \& Moradi, Y. (2021). Clinical manifestation and maternal complications and neonatal outcomes in pregnant women with COVID-19: a comprehensive evidence synthesis and meta-analysis. In Journal of Maternal-Fetal and Neonatal Medicine. https://doi.org/10.1080/14767058.2021.1888923

South, A. M., Brady, T. M., \& Flynn, J. T. (2020). ACE2 (Angiotensin-Converting Enzyme 2), COVID-19, and ACE Inhibitor and Ang II (Angiotensin II) Receptor Blocker Use during the Pandemic: The Pediatric Perspective. In Hypertension (Vol. 76, Issue 1). https://doi.org/10.1161/HYPERTENSIONAHA.120.15291

TIRMIKÇIOĞLU, Z. (2021). Evaluation of Updated Therapeutic Options For COVID-19 in Pregnancy and Lactation. Bezmialem Science, 9(1). https://doi.org/10.14235/bas.galenos.020.4652

TN, G., \& RA, S. (2020). Maternal and neonatal response to COVID-19. American Journal of Physiology. Endocrinology and Metabolism, 319(2).

Tug, N., Yassa, M., Köle, E., Sakin, Ö., Çakır Köle, M., Karateke, A., Yiyit, N., Yavuz, E., Birol, P., Budak, D., Kol, Ö., \& Emir, E. (2020). Pregnancy worsens the morbidity of COVID-19 and this effect becomes more prominent as pregnancy advances. Journal of Turkish Society of Obstetric and Gynecology, 17(3). https://doi.org/10.4274/tjod.galenos.2020.38924

Vaezi, M., Mirghafourvand, M., \& Hemmatzadeh, S. (2021). Characteristics, clinical and laboratory data and outcomes of pregnant women with confirmed SARS-CoV-2 infection admitted to Al-Zahra tertiary referral maternity center in Iran: a case series of 24 patients. BMC Pregnancy and Childbirth, 21(1). https://doi.org/10.1186/s12884-021-03764-y

Wang, Z., Wang, Z., \& Xiong, G. (2020). Clinical characteristics and laboratory results of pregnant women with COVID-19 in Wuhan, China. International Journal of Gynecology and Obstetrics, 150(3). https://doi.org/10.1002/ijgo.13265

Wastnedge, E. A. N., Reynolds, R. M., van Boeckel, S. R., Stock, S. J., Denison, F. C., Maybin, J. A., \& Critchley, H. O. D. (2021). Pregnancy and COVID-19. Physiological Reviews, 101(1). https://doi.org/10.1152/physrev.00024.2020 
medRxiv preprint doi: https://doi.org/10.1101/2021.06.11.21258747; this version posted June 18, 2021. The copyright holder for this preprint (which was not certified by peer review) is the author/funder, who has granted medRxiv a license to display the preprint in perpetuity. It is made available under a CC-BY-NC-ND 4.0 International license .

Wei, L., Gao, X., Chen, S., Zeng, W., Wu, J., Lin, X., Zhang, H., Sharifu, L. M., Chen, L., Feng, L., \& Wang, S. (2020). Clinical characteristics and outcomes of childbearing-age women with COVID-19 in Wuhan: Retrospective, single-center study. Journal of Medical Internet Research, 22(8). https://doi.org/10.2196/19642

Worldometer. (2020). Countries where Coronavirus has spread - Worldometer. Worldometer.

Xu, S., Shao, F., Bao, B., Ma, X., Xu, Z., You, J., Zhao, P., Liu, Y., Ng, M., Cui, H., Yu, C., Zhang, Q., Li, D., Tang, Z., \& Sun, P. (2020). Clinical manifestation and neonatal outcomes of pregnant patients with coronavirus disease 2019 pneumonia in Wuhan, China. Open Forum Infectious Diseases, 7(7). https://doi.org/10.1093/ofid/ofaa283

Yang, J., Zheng, Y., Gou, X., Pu, K., \& Chen, Z. (2020). Prevalence of comorbidities and its effects in patients infected with SARS-CoV-2. International Journal of Infectious Diseases, 94(April).

Yin, M. Z., Zhang, L. J., Deng, G. T., Han, C. F., Shen, M. X., Sun, H. Y., Zeng, F. R., Zhang, W., Chen, L., Luo, Q. Q., Yao, D. J., Wu, M., Yu, S. H., Chen, H., Baud, D., \& Chen, X. (2020). Severe acute respiratory syndrome coronavirus 2 (SARS-CoV-2) infection during pregnancy in China: A retrospective cohort study. In medRxiv. https://doi.org/10.1101/2020.04.07.20053744

Yockey, L. J., \& Iwasaki, A. (2018). Interferons and Proinflammatory Cytokines in Pregnancy and Fetal Development. In Immunity (Vol. 49, Issue 3). https://doi.org/10.1016/j.immuni.2018.07.017

2020) "Letter to Editor" Should women postpone childbearing during the COVID-19 pandemic? "Letter to Editor" Should Women Postpone Childbearing during the COVID-19 Pandemic?, 33(123). 